Received Date : 14-Jan-2016

Revised Date : 07-Jul-2016

Accepted Date : 12-Jul-2016

Article type : Article

만.

\title{
A Systematic Review of the Research on Vocabulary Instruction That Impacts Text Comprehension
}

Tanya S. Wright

Michigan State University, East Lansing, USA

Gina N. Cervetti

University of Michigan, Ann Arbor, USA

ABSTRACT

Although numerous studies have identified a correlational relationship between vocabulary and comprehension, we know less about vocabulary interventions that impact reading comprehension.

Therefore, this study is a systematic review of vocabulary interventions with comprehension outcomes. Analyses of 36 studies that met criteria are organized around (a) type of comprehension measure (i.e., comprehension of passages that included taught words or more generalized comprehension measures) and (b) type of intervention (i.e., direct teaching of word meanings or word-learning strategies). The authors looked for patterns in characteristics of vocabulary instruction within these analyses. Their findings led to four major themes: (1) Teaching of word meanings supported comprehension of text containing the target words in almost all cases; (2) instruction that focused on some active processing was typically more impactful than a definition or a dictionary method for supporting comprehension of text containing the target words, but we do not know how much instruction is sufficient; (3) there is very limited evidence that direct teaching of word meanings, even long-term, multifaceted interventions of large numbers of words, can improve generalized comprehension; and (4) there is currently no empirical evidence that instruction in one or two strategies for solving word meanings will impact generalized comprehension. However, studies that actively teach students to monitor their understanding of vocabulary and to use multiple, flexible strategies for solving word meanings are a promising area for

This is the author manuscript accepted for publication and has undergone full peer review but has not been through the copyediting, typesetting, pagination and proofreading process, which may lead to differences between this version and the Version of Record. Please cite this article as doi: $\underline{10.1002 / \mathrm{rrq} .163}$

This article is protected by copyright. All rights reserved 
future research. The authors discuss the implications of these themes, as well as critical avenues for future vocabulary research.

The ultimate goal of all reading-related instruction in schools is to help students comprehend text. Among the many factors that influence readers' abilities to make meaning from texts is their knowledge of the words in those texts. Dozens of studies conducted over the last century have documented a strong relationship between vocabulary knowledge and comprehension, finding, among other things, that the size of a person's vocabulary is one of the strongest predictors of his or her reading comprehension (Ricketts, Nation, \& Bishop, 2007; Sénéchal, Ouellette, \& Rodney, 2006; Thorndike, 1917).

Despite the consistency of this predictive relationship, there is evidence that schooling has a limited impact on students' vocabulary development (Christian, Morrison, Frazier, \& Massetti, 2000). As such, children who arrive at school with low levels of vocabulary knowledge are likely to continue to have relatively small vocabularies and are likely to struggle with text comprehension throughout their school lives (Catts, Adlof, \& Weismer, 2006; Cunningham \& Stanovich, 1997; Stanovich, 1986). A host of recent consensus documents and literacy standards have sought to change this, describing the importance of instructing vocabulary in school, and recommending explicit instruction of vocabulary words and strategies for determining the meaning of unknown words (National Governors Association Center for Best Practices \& Council of Chief State School Officers, 2010; National Institute for Literacy, 2008; National Institute of Child Health and Human Development, 2000). The argument underlying these instructional recommendations is that increased attention to vocabulary instruction in school will improve students' vocabulary knowledge and that this increased vocabulary knowledge will, in turn, improve students' reading comprehension.

Although there is strong evidence to substantiate the first part of this argument - that vocabulary instruction supports vocabulary learning (e.g., Biemiller \& Boote, 2006; FordConnors \& Paratore, 2015; Marulis \& Neuman, 2010)-less is known about the impact of vocabulary instruction on students' reading comprehension. Therefore, this article examines vocabulary interventions that seek to impact text comprehension. Specifically, we report the results of a systematic literature review and qualitative synthesis of this body of research to understand the characteristics of instruction in these studies. We were interested in describing vocabulary interventions that do and do not improve passage-level text comprehension. We 
examined studies of vocabulary interventions that measured comprehension outcomes using passages that included the words taught during the interventions and those that used more generalized comprehension measures that did not intentionally use the instructed words.

\section{Theory Relating Vocabulary to Comprehension}

The nature of the relationship between vocabulary knowledge and comprehension is not entirely understood. However, educational researchers have posited a reciprocal model in which vocabulary knowledge supports comprehension of text and text comprehension supports vocabulary learning (Nagy, 2005; Stanovich, 1986). That is, students who possess more vocabulary knowledge are likely to be better text comprehenders because they are more likely to know the meanings of the words contained in a text. Because reading is a meaningful activity for these students, they tend to read frequently and gain additional vocabulary knowledge incidentally from their extensive reading. In contrast, students with more limited early vocabulary knowledge struggle to gain meaning from text and tend to read less frequently, and therefore, they learn fewer new words from text (Cunningham \& Stanovich, 1997; Sénéchal et al., 2006). Those who recommend vocabulary instruction in schools seek to disrupt this cycle by boosting students' vocabulary knowledge or vocabulary-learning strategies to support text comprehension. Yet, it remains unclear whether vocabulary instruction can accomplish this goal and what types of vocabulary instruction might improve comprehension.

Anderson and Freebody (1981) described several hypotheses that seek to explain the well-documented relationship between vocabulary and comprehension. The aptitude hypothesis proposes that vocabulary and comprehension are linked by an underlying factor (i.e., general aptitude) that impacts both outcomes. Given its focus on an innate aptitude, this hypothesis has had limited instructional implications. The knowledge hypothesis suggests that vocabulary actually represents knowledge (i.e., a person who knows the word deglaze likely knows something about cooking), and it is the knowledge that boosts comprehension. However, studies investigating this hypothesis have found that knowledge and vocabulary may make distinct contributions to comprehension (e.g., Stahl, Hare, Sinatra, \& Gregory, 1991). Most vocabulary studies have ascribed to the instrumentalist hypothesis, which suggests that knowledge of a word's meaning directly impacts reading comprehension. Based on this hypothesis, to improve text comprehension, one must either lower the vocabulary demands in a text or ensure that readers know the meanings of a majority of the words in a text before reading. 
A final hypothesis, proposed by Mezynski (1983), focuses on speed of access to word meanings. From this perspective, the goal of vocabulary instruction is not only knowledge of a word's meaning but also easy access to the word's meaning in memory. If a word meaning is challenging to retrieve, the reader is forced to expend attentional resources that are needed for comprehension. This hypothesis led to a focus on interventions that involve depth of processing of word meanings. For example, Stahl and Fairbanks (1986) proposed a hierarchy in which association of a word with a definition reflects limited depth of processing, comprehension of a word's meaning (e.g., understanding a word in a sentence, providing an antonym) is evidence of greater depth of processing, and generation of a new response (i.e., using the word in an original sentence) is evidence of greatest depth of processing. Similarly, Beck, McKeown, and colleagues have focused on active processing of word meaning based on the premise that fluency of retrieval is better promoted when students actively engage with a word and its meaning (e.g., comparing and contrasting word meanings) rather than receiving information from the teacher (e.g., Beck \& McKeown, 1991; McKeown \& Beck, 2014).

\section{Vocabulary Instruction and Comprehension}

Although researchers have suggested that that the aptitude, knowledge, instrumentalist, and speed-of-access hypotheses likely each provide some explanation for the relationship between vocabulary and comprehension, the latter two theories have driven much of the vocabulary intervention research over the last half-century. Interventions based on the instrumentalist and speed-of-access hypotheses have taken one of two approaches to supporting comprehension: (1)

direct teaching of a set of word meanings (e.g., Apthorp et al., 2012; Stahl, 1983) or (2) teaching strategies for making sense of unknown words during reading (e.g., Baumann et al., 2002).

\section{Direct Teaching of Word Meanings}

The majority of vocabulary intervention studies with comprehension outcomes used direct teaching of word meanings to build students' vocabularies and support their comprehension. These studies typically examined students' comprehension of text soon after students were taught a set of words that appear in the text. Many of these direct teaching studies focused on active processing and depth over breadth in vocabulary instruction, using rich, multidimensional, and extended vocabulary instruction (e.g., Beck \& McKeown, 2007; Silverman, 2007) as a way of increasing both speed of access and retention of word meanings. Typically, this multifaceted instruction includes explanations of word meanings and multiple opportunities to encounter and 
use the word across contexts. Although many studies have found positive effects on word learning from direct teaching, we know less about how much and what type of vocabulary instruction - and how much active processing by students-is needed to support comprehension of a text containing the taught words.

A second possible implication of the instrumentalist hypothesis is to suggest that students should be taught a set of high-utility academic vocabulary words-words that appear frequently in academic texts—in the interest of ensuring that, over time, students begin to encounter fewer unknown words in texts. The question of whether it is possible to teach enough words to improve a student's general reading comprehension has been debated in the vocabulary literature. Nagy and Anderson (1984) described the futility of direct teaching of individual word meanings given the massive number of words that students need to know in order to comprehend school texts. Some vocabulary researchers have addressed this concern by arguing that it is critical to determine which words are most important to teach (Graves, 2015; Nagy \& Hiebert, 2010). Recently, scholars have argued for teaching sophisticated academic words that occur across school contexts (i.e., Tier 2 words; Beck, McKeown, \& Kucan, 2013). Yet, it remains unclear whether it is possible to teach enough of these academic words to impact students' reading comprehension broadly.

\section{Teaching Word-Solving Strategies}

Concerns about the vast number of words in school texts has led to vocabulary interventions that move beyond direct teaching of word meanings to focus on supporting students in learning strategies for deriving word meanings (e.g., from context, based on morphological knowledge), rather than direct teaching of word meanings (Baumann et al., 2002; Graves, 2006). Proponents of this type of strategy instruction have argued that students can use the ability to solve the meanings both to improve their comprehension of texts and to acquire new word knowledge over time. Similar to the pattern of research on direct teaching of word meanings, it is clear that when instruction is provided on word-solving strategies, students improve at applying these strategies (e.g., Baumann, Edwards, Boland, Olejnik, \& Kame'enui, 2003; Kieffer \& Lesaux, 2012). What remains unclear is whether there is evidence that instruction in word-learning strategies leads to improvements in text comprehension. 


\section{Previous Meta-analyses and Syntheses}

To tackle some of these questions, two meta-analyses have examined vocabulary interventions that include comprehension outcomes (Elleman, Lindo, Morphy, \& Compton, 2009; Stahl \& Fairbanks, 1986). Both meta-analyses found overall positive effects for vocabulary interventions on comprehension outcomes, particularly for comprehension of passages that include the vocabulary words that were directly taught in the intervention. For example, in their metaanalysis of 52 studies on vocabulary instruction, Stahl and Fairbanks found that vocabulary instruction improves students' reading comprehension of passages, with a stronger effect on passages that contain the words that were taught (effect size $=.97$ ) than for global measures of comprehension (i.e., those that do not contain the taught words; effect size $=.30$ ). Based on a comparison of effect sizes, Stahl and Fairbanks concluded that the most effective vocabulary teaching methods included both definitional and contextual information in their programs, involved the students in deeper processing, and gave students more than one or two exposures to the to-be-learned words.

Elleman et al. (2009) updated Stahl and Fairbanks's (1986) meta-analysis by using newer analytic methods. Elleman et al. included only studies of K-12 instruction (whereas Stahl and Fairbanks included studies of adults) and only studies that included a passage comprehension outcome (i.e., versus other kinds of measures such as cloze tests). In total, Elleman et al. included 37 studies in their meta-analysis. Unlike Stahl and Fairbanks, Elleman et al. compared all researcher-designed (custom) measures, regardless of whether they contained taught or untaught words, with standardized measures. The researchers found larger effects of vocabulary instruction on the custom measures (Hedges's $g=0.50$ ), with minimal effects for standardized measures (Hedges's $g=0.10$ ). The researchers suggested that the difference in effect sizes across the two meta-analyses may be due either to differences in the included studies or to the more conservative methods used to evaluate effects in the newer meta-analysis (e.g., different effect size calculations). Elleman et al. found stronger effects on comprehension when the participants receiving the treatment were reading below grade level and smaller effects when studies included more stringent control groups.

Unlike Stahl and Fairbanks (1986), Elleman et al. (2009) were unable to consider instructional variables such as depth of processing. They argued that there were too few studies across instructional categories to conduct a moderator analysis and that direct statistical 
comparison of these studies, as was done in the early meta-analysis, is methodologically tenuous because there were not enough studies to represent all levels of each factor. In addition, some of the variance attributed to these instructional variables could be due to methodological and participant factors that could not be taken into account. Therefore, although the researchers were able to update and substantiate Stahl and Fairbanks's overall findings, they were unable to provide information related to the specific characteristics of vocabulary instruction that impacted comprehension. Also, because they compared custom and standardized measures, Elleman et al. did not distinguish between comprehension of passages with taught words and more generalized comprehension.

In addition to Stahl and Fairbanks's (1986) and Elleman et al.'s (2009) meta-analyses, there have also been several qualitative reviews that focused specifically on vocabulary interventions with comprehension outcomes. Mezynski (1983) reviewed eight studies that attempted to improve reading performance by teaching vocabulary. Methods for locating and selecting these studies were not provided. However, based on the included studies, Mezynski concluded that there appeared to be three important variables that mattered for vocabulary instruction to transfer to comprehension: "(1) amount of practice given to the words, (2) breadth of training in the use of the words, and (3) the degree to which active processing is encouraged" (p. 273).

The National Reading Panel (National Institute of Child Health and Human Development, 2000) also attempted to look systematically at the impact of vocabulary instruction on comprehension. Although they found too few studies that met criteria for their intended meta-analysis, based on a qualitative review, they concluded that vocabulary instruction can impact comprehension. The researchers were unable to draw specific conclusions about the characteristics of effective instruction because the studies with comprehension outcomes "typify the heterogeneity among definitions and implementations of vocabulary instruction" (p. 4-20). Other reviews (e.g., Baumann, 2005; Baumann, Kame'enui, \& Ash, 2003; Blachowicz \& Fisher, 2000; RAND Reading Study Group, 2002) include sections summarizing studies of vocabulary with comprehension outcomes. Yet, none of these reports includes a systematic review of the literature.

This article is protected by copyright. All rights reserved 


\section{The Current Study}

Given the practical importance of understanding what we do and do not yet know based on vocabulary interventions that may impact comprehension, we undertook the present study to systematically examine relevant research. Although there have been several syntheses and book chapters (see the previous discussion) addressing the topic of the relationship between vocabulary and comprehension, it is not apparent that the qualitative reviews relied on exhaustive methods for searching the literature with the focus on including all relevant intervention studies that met criteria. Therefore, the first goal of this study was to complete a systematic search of the literature to ensure the inclusion of all available peer-reviewed vocabulary intervention studies with passage-level comprehension outcomes that we could locate. Given the large number of vocabulary intervention studies published in the past decade, we were also interested in how findings from newer studies might contribute to the discussions in earlier chapters and meta-analyses.

Because this research has been considered too heterogeneous for statistical moderator analyses, our second goal was to use qualitative coding and analytic strategies to look for patterns in the characteristics of vocabulary interventions that do and do not impact comprehension. Rather than being deterred by the broad range of definitions, instructional strategies, research designs, and measures in these studies, we were interested in whether we could identify common patterns despite these differences. Therefore, in this review, we included a broad range of yocabulary interventions implemented with prekindergarten through 12th-grade students, including those that focused on direct teaching of word meanings and interventions focused on teaching word-solving strategies. All of the selected studies included a passage comprehension outcome-either using taught-word comprehension outcome measures (i.e., listening or reading comprehension measures using texts including the vocabulary words that were taught as part of the instructional intervention) or generalized comprehension measures (i.e., researcher-designed or standardized measures of comprehension of texts that did not intentionally include vocabulary words that were taught in the instructional intervention). We then coded these studies based on characteristics of instruction and on research design characteristics. Specifically, we were interested in what we could discern descriptively about characteristics (e.g., type of intervention, duration, attention to active processing, word selection) of vocabulary instruction that might support comprehension of connected text. 
Finally, our third goal was to use these analyses to make recommendations to inform future research on vocabulary instruction. We were interested in establishing what we currently know and whether earlier claims hold up to systematic inquiry that includes results of newer studies. Therefore, for each important characteristic, we created counts that enabled us to examine the number of studies with similar patterns of findings. However, we were also interested in using this analysis to systematically analyze what we do not yet know. Therefore, we carefully describe outlier studies and inconsistencies in patterns to understand whether these might suggest fertile pathways for future vocabulary research.

\section{Method}

\section{Study Selection}

We searched ERIC using the ProQuest interface and the References sections of previous metaanalyses and reviews. We applied the following six criteria in selecting studies for this analysis:

1. The study was (broadly) a vocabulary intervention and not a naturalistic study of the relationship between vocabulary knowledge and comprehension.

2. The study included a passage-reading or listening comprehension outcome measure (e.g., read and respond to question, read and retell, sentence verification), which is either a proximal measure of comprehension of a text containing taught words or a generalized comprehension measure of a passage that does not intentionally contain taught words. We included studies that had other outcomes, such as vocabulary learning, as long as there was also a separate passage comprehension measure.

3. The study appeared in a peer-reviewed journal. Given our interest in describing effective instruction, we were interested in research that had been vetted by the peer review process.

4. The study included more than one condition. We included studies with the following research designs: between-subjects comparison of multiple treatments, between-subjects comparison of treatment(s) with a no-treatment control, within-subjects comparison of multiple treatments, and within-subjects comparison of treatment(s) with a no-treatment control.

5. The study was published in English. 
6. The study focused on the prekindergarten through secondary levels, not postsecondary.

We searched for studies using the term

vocabulary AND (comprehension OR recall OR retelling OR retell OR inferencing OR inferences) AND at least one of the following terms: context clues, context cues, gloss, glosses, implicit, instruction, intervention, interventions, learning, lexical, selection, metacognitive, morphological, morphology, semantic feature, semantic features, strategies, strategy, taught, teaching, word analysis, word learning, word meaning, word meanings.

We searched all terms using * for inflected endings. These initial searches provided 864 references. Out of concern that we might have missed studies focused on younger students where vocabulary was taught during shared reading with listening comprehension outcomes, we conducted follow-up searches using the terms "vocabulary AND (comprehension OR recall OR retelling OR retell OR inferencing OR inferences) AND at least one of the following terms: shared reading, dialogic reading, read-aloud, read aloud, listening." We found an additional 517 references. Two doctoral students in education read the abstracts for each source to determine whether each study met our study inclusion criteria. Questions were resolved through discussion with us. A third doctoral student checked this list again by reading and summarizing each of the identified studies.

At this point, we read each article in full and prepared a summary of each that included descriptions of the sample, intervention, measures, and outcomes. Studies were excluded if comprehension instruction or content instruction was combined with vocabulary instruction in a manner that prevented us from being able to understand the distinct contribution of vocabulary (e.g., Jackson \& Dizney, 1963). Because our focus is on text comprehension at the passage level ( similar to Elleman et al., 2009), we excluded studies that only used cloze measures of comprehension. Cloze measures have been critiqued as questionable comprehension measures because they are not sensitive to comprehension that reaches across sentences in a passage (for further discussion of these issues, see Pearson \& Hamm, 2005). We also excluded studies that did not report results of a separate passage comprehension measure (i.e., comprehension was combined with vocabulary; e.g., Korat \& Shamir, 2012). Given our interest in vocabulary instruction, we excluded studies in which the only intervention was a direct translation of the full text (e.g., Hsu, Hwang, Chang, \& Chang, 2013). We excluded studies if we could not determine 
whether the comprehension measure included taught vocabulary (e.g., Taboada \& Rutherford, 2011), as this was a question of interest for our work. We excluded studies that were secondary analyses of data from another included study (e.g., Crevecoeur, Coyne, \& McCoach, 2014). Table 1 provides a summary of inclusion criteria used in this analysis compared with previous meta-analyses.

\section{[COMP: Please insert Table 1.]}

\section{Data Coding and Analysis}

\section{Instructional Characteristics}

We coded each of the selected studies based on a series of characteristics relevant to the analysis, including characteristics related to the nature and duration of instruction.

\section{Type of Intervention}

We coded each study for the intervention approach at two levels. At the first level, we distinguished interventions that focused on direct teaching of word meanings or word-solving strategies. At the second level, we focused on more specific instructional characteristics. Within studies of direct teaching of word meanings, we applied codes that characterized the methods for direct instruction of word meanings (e.g., use of instructional aids such as semantic feature analysis charts, graphic organizers, or dictionaries). For strategy instruction, we coded for the taught strategies (e.g., context cues, morphological instruction). Where there were multiple vocabulary conditions, we carefully documented the differences between each group.

\section{Participants}

We coded each study for the age or grade of study participants. We also examined other sample characteristics where this information was available (e.g., socioeconomic status, language status, reading level).

\section{Duration of the Intervention}

For studies that provided information about instructional time, we calculated the total number of minutes of instruction provided and the time span (i.e., did instruction occur over the course of hours, days, weeks, or months?) of the intervention. Interventions that lasted more than four weeks were classified as long-term programs of instruction.

\section{Average Minutes of Instruction per Word}

Where possible, we calculated the average minutes of instruction per word by dividing the total minutes of instruction by the number of words taught. The latter measurement was only applicable in interventions that focused on direct instruction of a particular set of words. 


\section{Active Processing}

We coded each intervention condition for whether students were required to interact with the meaning of a word (i.e., compared with being told the meaning of a word by an instructor or computer). We were guided by Stahl and Fairbanks's (1986) depth-of-processing scheme. For example, we considered the condition to include active processing if students compared and contrasted word meanings, answered questions about the meaning of the word, created their own definitions, wrote sentences that used the word, or engaged in semantic mapping or semantic feature analysis.

\section{Type of Words Taught}

For studies in which a particular set of words was taught, we recorded any information about the researchers' approaches to word selection.

\section{Research Design Features}

In addition, we examined each of the selected studies based on a series of research design features that were relevant to the analysis and helped us consider the quality of the studies. Type of Comprehension Measure and Effects

We coded each study according to whether the researchers used a taught-word comprehension outcome measure (i.e., the taught words were included in the comprehension passage in the assessment) or a generalized comprehension measure (i.e., taught words were not included) and whether the study found effects for the treatment relative to a control or comparison group. This coding aligns with Stahl and Fairbanks's (1986) coding scheme. At the second level, we characterized the measures as researcher-developed or standardized, using the dichotomy from Elleman et al.'s (2009) meta-analysis.

\section{Study Design}

Study designs were coded as between-subjects comparison of multiple treatments, betweensubjects comparison of treatment(s) with a no-treatment control, within-subjects comparison of multiple treatments, or within-subjects comparison of treatment(s) with a no-treatment control. Assignment to Condition

We categorized each study based on whether participants were randomly assigned to condition or nonrandom and whether assignment was at the child, classroom, or school level. For studies with nonrandom assignment, we examined pretest measures used to establish equivalence or used as covariates in analyses of the impact of the intervention on comprehension outcomes. In within-subjects designs, we recorded whether the treatment order was counterbalanced. 
In the first round of coding, we each coded half of the studies. We then completed a second round of coding where studies were randomly assigned to one of us to check the accuracy of the initial codes. We used a series of matrices to cluster studies according to the major codes of interest (Miles \& Huberman, 1994). For each analysis, we display the findings of the included studies in table form, we include counts of studies that did and did not impact the comprehension outcome measure, and we then describe the included studies in more detail and explain themes that emerge when we examine the studies as a group. Results of some studies are included in multiple sections of the analysis. For example, if a study included both a taught word and a generalized comprehension measure, we analyzed instruction and effects in each of these categories. We provide information about each study in the Appendix (available as supporting information for the online version of this article), including a description of the study participants, instructional conditions, word selection and the number of words taught, and the duration of the intervention, as well as detailed explanations of the study design, treatments, and comprehension measures.

\section{Results}

\section{Overview of the Studies}

Our final sample included 36 studies. Eleven of these studies were published since 2006 and, therefore, were not included in previous meta-analyses. Of the 36 studies, the majority (22 studies) focused on students in grades 3-5. The participants in five studies were kindergarten through second-grade students; in five studies, they were middle school students (grades 6-8); and in four studies, they were high school students (grades 9-12). We found no prekindergarten studies that met the study criteria. The participants in the studies included students with a broad range of background characteristics. We describe these characteristics as we discuss the exemplar studies, and we provide more detailed information about the participants in the Appendix.

Although word selection strategies were of particular interest in this study, we found limited variability across studies. Almost all studies selected challenging words from one or more texts using some type of nomination process (i.e., by teachers or experts, by other students during a pilot, based on curricular materials). Six studies selected words directly from a vocabulary list (e.g., Coxhead, 2000; Dale \& O’Rourke, 1981). Four studies combined teacher nomination and the word's presence on an existing vocabulary list. Given the overwhelming 
similarity of word selection techniques, we were unable to look for patterns of findings using the word selection code. Therefore, we primarily describe outlier studies if they used alternate strategies for word selection (i.e., beyond nomination of challenging words or word lists). Information about word selection for each study is included in the Appendix.

The Results subsections that follow are organized primarily by type of comprehension measure (i.e., taught word or generalized) and whether the intervention had effects on that measure. We viewed these different measures as indications of different instructional goals for the intervention. The studies with taught-word comprehension measures were typically seeking to understand how vocabulary instruction could boost comprehension of a particular text containing taught words. Studies that included generalized comprehension measures were typically attempting to use strategy instruction or long-term or more in-depth instruction of large numbers of words to boost students' comprehension more generally. Within these sections, we compared studies based on instructional characteristics with type of intervention-whether the study focused on direct teaching of word meanings or on strategy instruction-as our secondary method of organization. At the third level, we examined other instructional characteristics of these studies to look for meaningful patterns that might inform current practice and future research.

\section{Studies With Taught-Word Comprehension Measures}

The majority of the studies included in this research synthesis examined the impact of interventions that involved direct teaching of word meanings on comprehension of passages that included the taught target words. We found a total of 25 studies in this category. Two of these studies combined direct teaching of word meanings with strategy instruction. Although studies varied greatly in the details of their instructional methods, 21 of the 25 studies (19 direct teaching studies and the two that combined direct teaching with strategy instruction) found

significant effects for at least one condition on the taught-word comprehension measure. Therefore, in most cases, teaching students the meanings of the words in a passage supported students' comprehension of that passage. Below we describe and compare some of the characteristics of these effective studies and then consider what we might learn from the four outlier studies that did not have effects. 


\section{Brief Direct Instruction of Word Meanings}

As shown in Table 2, the 19 direct teaching studies with significant positive effects on taughtword comprehension measures ranged in overall duration and in the instructional time (minutes per word) dedicated to teaching word meanings. Some studies involved very brief interventions. For example, three studies compared brief direct teaching of word meanings in the context of reading or read-alouds to an exposure-only condition (no instruction; Greene Brabham \& LynchBrown, 2002; Hawkins, Musti-Rao, Hale, McGuire, \& Hailley, 2010; Kame'enui, Carnine, \& Freschi, 1982). All three studies demonstrated that providing even brief instruction on word meanings before or during reading is more effective for supporting comprehension than exposure to the words through reading alone. For example, in Hawkins et al.'s study, the treatment involved having the fourth-grade students pronounce each word and then the teacher read a definition and sentence for each word directly before students read the text. We estimated that this routine required less than one minute per word. Yet, even this brief instructional attention to word meanings improved passage comprehension compared with exposure during reading alone.

\section{[COMP: Please insert Table 2.]}

Similarly, the treatment in two studies involved giving students access to glosses while they read on a computer (i.e., the computer provided students with information about word meanings during reading; Reinking \& Rickman, 1990; Türk \& Erçetin, 2014). Reinking and Rickman found that requiring sixth graders to access definitions while they read on a computer was more effective for supporting comprehension than giving students a dictionary and allowing them to choose whether to access definitional information. Similarly, Türk and Erçetin found that requiring Turkish ninth-grade students to view verbal and visual definitional information about a word was more effective for supporting their English text comprehension than letting students choose either the verbal or visual information.

Four studies compared brief preteaching of word meanings before (i.e., immediately before to a few days before) reading a text that included those words with a no-treatment control group (Carney, Anderson, Blackburn, \& Blessing, 1984; Medo \& Ryder, 1993; Pany, Jenkins, \& Shreck, 1982; Stahl, 1983). Although these studies were more likely to attend to active processing than those described previously, instruction was brief, lasting from one to four hours total and devoting two to 10 minutes to preteaching each word's meaning. Preteaching methods included providing definitions, use of the word in context, and/or brief discussions about each 
word. For example, Pany et al. taught 12 target words to fourth-graders by having the instructor show students the printed words, read the words aloud, provide a synonym, and then state a sample sentence containing the words. Although the intervention was brief in duration (a total of 60-120 minutes to learn this information to criterion), the students performed better on comprehension questions assessing parts of the passage containing the taught words compared with sections that contained untaught control words.

Therefore, despite substantial recent attention to longer term and more robust instruction of word meanings, taken together, these studies suggest that even brief interventions that provide information about word meanings had positive impacts on comprehension.

\section{Longer Term and More Time-Intensive Direct Instruction of Word Meanings}

Four studies that showed effects on taught-word comprehension passages compared with a notreatment control were long-term (i.e., typically lasting five or six months) programs of vocabulary development (Apthorp et al., 2012; Beck, Perfetti, \&McKeown, 1982; Lesaux, Kieffer, Kelley, \& Harris, 2014; McKeown, Beck, Omanson, \& Perfetti, 1983). This set of studies differed from the briefer direct teaching studies in several important respects. First, overall duration of these studies was substantially greater, as was the number of minutes devoted to the instruction of each word (i.e., often upward of 20 minutes per word). Second, the time lapse between instruction and assessment was longer. In these studies, the comprehension assessment was typically administered at the end of a months-long program. Third, the nature of the instruction was different in that these interventions included a broad range of instructional activities to support learning word meanings. Activities included introducing words during reading using contextual and definitional information, applying word meanings through various word games and activities, exploring relationships among words, and extension activities at home.

These studies of programs of vocabulary development also included multiple encounters with each word over time. For example, Lesaux et al. (2014) involved more than 2,000 linguistically diverse sixth-grade students in a 20-week intervention, involving 45 minutes of intensive vocabulary instruction each day on a total of 70 target words (for an average of almost 60 minutes of instruction per word). Students were exposed to the words in context, connected the word meanings to prior knowledge, learned additional meanings and uses for the words, analyzed the words morphologically, used them in writing, and reviewed them using cooperative 
games. The students in the treatment condition outperformed a no-treatment control group on a measure of expository text comprehension that included the taught words. As will be discussed in a later section, treatment students did not make greater gains on a generalized comprehension measure.

Therefore, most studies, whether they provided students with brief information about word meanings or were longer term, more intensive programs that taught word meanings, led to improved comprehension compared with no intervention when taught words were embedded in the comprehension passages. Although long-term programs clearly had different instructional goals (i.e., to build student's vocabulary more generally, to support students in being able to retain word meanings and access them fluently over a longer period of time), it remains unclear whether this more replete and time-consuming instruction has advantages for supporting taughtword comprehension compared with less-intensive interventions.

\section{Studies Comparing Direct Word-Teaching Methods}

Although the weight of the evidence suggests that direct teaching of word meanings—both brief and time-limited instruction and long-term programs-support comprehension of passages containing taught words compared with no instruction at all, the question remains about the relative effectiveness of different approaches to teaching words to support passage comprehension. Fifteen studies compared the effects of different methods for direct teaching of word meanings on a taught-word comprehension measure (see Table 3).

\section{[COMP: Please insert Table 3.]}

Seven studies compared instructional approaches focused on greater active processing with a definition or dictionary method (i.e., treatments in which students were either provided definitions for the words or looked up the words in dictionaries; Bos \& Anders, 1990, 1992; Bos, Anders, Filip, \& Jaffe, 1989; McKeown, Beck, Omanson, \& Pople, 1985; Nash \& Snowling, 2006; Stahl, 1983; Wixson, 1986). All of these interventions were relatively brief in duration but ranged broadly in time spent on teaching individual word meanings (from two to 20 minutes per word).

In these studies, methods in one of the treatment conditions were typically more interactive compared with the definition or dictionary methods. For example, in Bos and colleagues' (Bos \& Anders, 1990, 1992; Bos et al., 1989) and Nash and Snowling's (2006) studies, experimental treatments included semantic mapping or semantic feature analysis. In 
McKeown et al.'s (1985) study, the experimental treatments focused on rich instruction (i.e., including matching words with definitions, associating a word with a context, creating contexts for words, comparing and contrasting words to discover relationships). In five out of seven cases, the treatment involving more active processing had greater effects on a taught-word comprehension measure administered immediately following the intervention (Bos \& Anders, 1990, 1992; Bos et al., 1989; McKeown et al., 1985; Nash \& Snowling, 2006). In addition, the studies by Bos and colleagues demonstrated that findings in favor of the active-processing groups were maintained at follow-up four to six weeks later.

Two studies that seemingly did not show effects for the active-processing condition compared with the definition treatment were Stahl (1983) and Wixson (1986). In Stahl's study, although both treatments performed better than a no-treatment control, there was no advantage for the fifth-grade students when they received definition plus contextual treatment compared with the definition-only treatment. However, upon a detailed analysis of the conditions, it becomes clear that the differences between the two treatments were fairly subtle and that both involved active processing; following discussion of the words' meanings, students in the definition plus contextual treatment produced sentences using the words, whereas students in the definition-only treatment produced their own definitions. Wixson compared average and aboveaverage fifth grade readers' comprehension of a narrative text. Some students were pretaught unfamiliar words that were most central to the story, whereas others were taught unfamiliar words that were less central to the story. Students were taught words using either a dictionary method (look up each word and write a sentence for it) or a concept method (students discussed examples and nonexamples to determine critical attributes of a word, and the instructor guided students to a definition of it). Similar to Stahl's study, students in both conditions had the opportunity to actively apply the word meaning. Wixson found that students who were taught central vocabulary comprehended ideas in the story that contained these words, whereas students taught noncentral vocabulary comprehended ideas that contained noncentral words. Yet, there was no clear advantage for either vocabulary teaching method on passage comprehension overall.

In studies that compared multiple, interactive approaches, it is difficult to determine whether particular instructional methods are superior, because studies ranged broadly in the details of their treatments and in their duration. For example, McKeown et al. (1983) found that 
students performed better on comprehension questions in a text containing words that had been reviewed more often; however, when Bos and Anders (1990) compared several instructional conditions that promoted active processing, all were equally effective in promoting passage comprehension compared with a definition-only approach.

When taken in conjunction with the earlier analyses in this review, studies comparing different instructional treatments suggested that more attention to active processing has a stronger impact on comprehension of passages containing the taught words compared with more receptive approaches, such as exposure during reading, brief definitions, or a dictionary method. However, given the broad range of methods and differing amounts of instructional time spent per word in the active-processing interventions, it is difficult to determine which methods might be most effective and whether there are instructional benefits to more time and focus per word.

\section{Studies That Combined Direct Teaching and Strategy Instruction}

Two taught-word comprehension studies combined direct teaching of word meanings with instruction on strategies to support independent vocabulary learning. Dole, Sloan, and Trathen (1995) found that 10th-grade students who were taught how to select vocabulary to learn and how to study these words at a deep level scored better on a taught-word comprehension task than students who received more traditional (i.e., teacher-directed) vocabulary instruction. Levin, Levin, Glasman, and Nordwall (1992) found that students who were taught to use a mnemonic keyword to support word learning scored better on taught-word comprehension than students who learned a definition and students who engaged in free study of vocabulary words. In both studies, providing students with strategies to support their word learning had added benefits for taught-word comprehension.

\section{Direct Teaching Studies That Did Not Impact Taught-Word Comprehension}

Four outlier studies did not find a significant positive effect for vocabulary instruction on taughtword passages (Coyne et al., 2010; McKeown \& Beck, 2014; Seifert \& Espin, 2012; Tuinman \& Brady, 1974). Although there were only three studies in our analysis that included kindergartners, two of these (Coyne et al., 2010; McKeown \& Beck, 2014) were included in this no-effects group. In Coyne et al.'s study, kindergartners participated in a program in which they were taught 54 Tier 2 words (high-utility general academic words) over 18 weeks. Treatment students made gains on knowledge of the taught vocabulary words compared with a business-asusual control group but did not significantly outperform the control on the taught-word listening 
comprehension measure. Researchers found a significant interaction such that treatment students with higher pretest vocabulary scores made greater gains on listening comprehension. In McKeown and Beck's study, kindergartners learned 30 Tier 2 words in one of two treatment conditions (more and less interactive word learning) or a read-aloud comparison group. Although both treatment groups learned more word meanings compared with the control group, there were no differences compared with the read-aloud-only group on the listening comprehension measure.

In Seifert and Espin's (2012) study, 10th-grade students identified as having learning disabilities received two hours of vocabulary instruction focused on 10 words from a science text. This vocabulary intervention involved direct teaching of a definition, providing students with contextual information, and posing two probing questions to practice applying the word. Although there were no significant differences across treatments on the taught-word comprehension measure, the researchers suggested that with a small sample $(N=20)$, outlier scores may have impacted these findings. Without the outliers, findings trended toward the treatment condition. In Tuinman and Brady's (1974) study, students in grades 4-6 used selfguided vocabulary-learning materials to study sets of words. Comprehension was then tested on passages that included the taught words and passages that did not. Although students learned the words that were taught, they demonstrated no differences in comprehension across the two types of passages.

Therefore, in two studies that did not demonstrate statistically significant findings (Coyne et al., 2010; Seifert \& Espin, 2012), results on taught-word comprehension still trended toward the treatment aligning with the overall pattern of results across studies. Also, two of these studies involved kindergartners and listening comprehension measures (Coyne et al., 2010; McKeown \& Beck, 2014), suggesting that young learners may require alternative vocabulary instruction methods or more sensitive comprehension measures.

\section{Studies With Generalized Comprehension Measures}

A second set of vocabulary intervention studies included measures of generalized comprehension (i.e., taught words were not embedded in the comprehension passage). We found a total of 16 studies in this category. ${ }^{1}$ Of these, seven studies focused only on direct teaching of word meanings, six studies focused primarily on strategy instruction, two studies combined direct teaching of word meanings with strategy instruction, and one study compared direct teaching 
with strategy instruction. Although the studies varied in the details of their instructional methods, only four of the 16 studies (two direct teaching studies and two strategy instruction studies) found effects for at least one condition on the generalized comprehension measure. Next, we describe some characteristics of studies that were not effective and then consider what we might learn from the four outlier studies with significant, positive effects on generalized comprehension.

\section{Studies of Direct Teaching of Word Meanings}

Nine of the generalized comprehension studies used multifaceted interventions to directly teach word meanings (Apthorp, 2006; Apthorp et al., 2012; Beck et al., 1982; Lesaux, Kieffer, Faller, \& Kelley, 2010; Lesaux et al., 2014; McKeown et al., 1985; Nash \& Snowling, 2006; Nelson \& Stage, 2007; Simmons et al., 2010). Most of these studies selected words from academic word lists or words judged to be high-utility academic words, and used multiple, active methods for supporting students' learning of the meanings of the words, including associating a word with a definition or synonym, learning the word across multiple contexts, creating contexts for words, comparing and contrasting words to discover relationships, sentence generation tasks, classification tasks, oral and written production tasks, gamelike tasks completed under timed conditions, tasks that take advantage of the semantic or affective relationships between the target words and previously acquired vocabulary, tasks that ask students to engage with the target word outside of class, morphological analysis of words, and tasks that connect word meanings to prior knowledge. As shown in Table 4, these interventions were generally time-intensive, allowing six to 26 instructional minutes per taught word.

\section{[COMP: Please insert Table 4.]}

Two studies focused primarily on multifaceted word teaching but also included some morphology (i.e., strategy) instruction (Lesaux et al., 2010, 2014). In the 2010 study, Lesaux and colleagues provided sixth-grade students who were mostly from language-minority backgrounds with multifaceted vocabulary instruction of 72 word meanings and lessons on morphology and using context cues. Although the researchers found effects on other measures (e.g., students learned taught words and improved in their morphological knowledge), neither the 2010 study nor the 2014 study, which employed a similar intervention, documented significant gains on a standardized general comprehension measure. Notably, both studies included more instructional time per word than any other study in our sample. 
Of the nine studies, only two found generalized comprehension effects compared with a no-treatment control (Beck et al., 1982; Nelson \& Stage, 2007). In Beck et al.'s study, 23 fourthgrade students from low-income families in one classroom received instruction on 104 words that were drawn from fourth-grade curricular materials and grouped for instruction in semantic categories (e.g., people, what you can do with your arms, moods). Instruction included defining tasks, sentence generation tasks, classification tasks, oral and written production tasks, and tasks designed to form associations across target words. The treatment group outperformed the notreatment, matched pretest control (i.e., other students in the same school) on the Iowa Tests of Basic Skills reading subtest. Although this is a promising finding, researchers who employed similar interventions in five more recent studies have not been able to replicate the significant, positive generalized comprehension effects.

In the second study with positive effects for generalized comprehension (Nelson \& Stage, 2007), 283 students in grades 3 and 5 were taught 36 target words and three related words to represent additional word meanings for a total of 144 words (e.g., for the word accident, students also learned fluke, mishap, and by chance). Word selection methods differed from any other study that we reviewed. Words were initially selected from The Living Word Vocabulary list (Dale \& O'Rouke, 1981) if they had two to four mutually exclusive meanings and if fourth to sixth graders were likely to struggle with them (i.e., familiarity scores were not available for the word list for grade 3). The authors then used The Educator's Word Frequency Guide (Zeno, Ivens, Millard, \& Duvvuri, 1995) to ensure that the final selected words were in the 1,000 most frequent words and were widely used words in texts for grades 3-6. To learn the words, students examined and discussed sentences that used the words in context. They also learned the history of each target word, created word-meaning maps, practiced multiple meanings for each target word, and wrote short stories using the target words. Therefore, this study differed substantially from others in this category in both its selection of words and some aspects of the instruction, such as a focus on polysemy (i.e., many possible meanings for a word). Third-grade students with low and average-to-high initial vocabulary and comprehension made greater gains than control students on the Gates-MacGinitie Reading Test comprehension scale. Fifth graders with low initial vocabulary and comprehension had similar results; however, there were no significant differences for fifth graders who started with average-to-high pretest scores. 
Together, these studies provide little support for the efficacy of long-term, multifaceted interventions for improving generalized comprehension. Despite substantial instructional attention to direct teaching of word meanings, only two of the nine studies in this analysis showed a statistically significant impact on students' generalized comprehension compared with no intervention at all.

\section{Studies of Strategy Instruction}

Seven generalized comprehension studies focused on vocabulary strategy instructionsupporting students in learning to determine the meanings of unknown words-rather than direct instruction of particular words. See Table 5 for results of these studies. Of these studies, five showed no effects on generalized comprehension measures relative to comparison groups, one had effects on generalized comprehension, and one eliminated differences between students in a Title I school compared with above-average readers in a more advantaged school.

\section{[COMP: Please insert Table 5.]}

All five strategy studies with no effects on generalized comprehension involved instruction in one or two word-solving strategies. Two of the studies involved a treatment focused on using context clues to determine word meanings (Hafner, 1965; Tomesen \& Aarnoutse, 1998). Other instructional interventions included morphology and context clues instruction (Baumann et al., 2002) and semantic ambiguity training (Zipke, Ehri, \& Cairns, 2009).

One study compared strategy instruction (i.e., morphology and context clues) with direct teaching of word meanings (Baumann, Edwards, et al., 2003). Although the students in the strategy treatment improved on measures of their strategy use (e.g., students in the morphology group improved on a morphology measure, students in the direct teaching group improved on learning word meanings), neither group had stronger outcomes on the generalized comprehension measure.

Taken together, these studies provided no empirical evidence that instruction in one or two strategies for solving word meanings impacts generalized comprehension. However, two studies employing broader conceptions of strategy instruction had effects and suggested promising ideas for future research (Lubliner \& Smetana, 2005; Sampson, Valmont, \& Van Allen, 1982). Lubliner and Smetana taught fifth-grade students from a low-performing Title I school to actively monitor their understanding of word meanings during reading, as well as 
numerous wordlearning strategies for clarifying a word's meaning (e.g., consider the context, study the structure, mine your memory, substitute a synonym). Some direct teaching was included when teachers reviewed the meanings of student-identified words at the end of the lesson. Students in the treatment group received 18 hours of instruction over 12 weeks and caught up to more advantaged peers (in an above-average performing school) on comprehension of new, researcher-designed texts that did not include vocabulary words discussed during the intervention.

Sampson et al. (1982) provided small-group instruction to third-grade students, focusing on a series of 27 cloze exercises. The cloze tasks were structured so students had to consider both semantic and syntactic language constraints for missing vocabulary. Students worked on the cloze tasks independently and then discussed words that could satisfy the semantic and syntactic constraints with their teacher during reading centers. Treatment students scored higher than the business-as-usual control group on a generalized, standardized comprehension measure.

These two studies provide preliminary evidence that actively teaching students to monitor their understanding of vocabulary and to use multiple, flexible strategies for solving word meanings may be a promising approach to supporting students' comprehension of passages, including their generalized comprehension of passages that do not contain pretaught words.

\section{Discussion}

This synthesis examined 36 studies that tested the impact of one or more vocabulary interventions on passage comprehension. A recent meta-analysis (Elleman et al., 2009) was unable to provide information about specific instructional characteristics that impacted text comprehension. Therefore, the goals for this analysis were to complete a systematic review of the literature, to look for themes that might help us understand the broad range of instructional interventions, and to understand how these patterns, as well as studies that did not fit the patterns, might suggest future avenues for vocabulary instruction research. In this section, we discuss these patterns of findings and consider how these might inform future research.

We found four major themes:

1. Teaching word meanings supported comprehension of text containing the target words in almost all cases. 
2. Instruction that focused on some active processing was typically more impactful than a definition or dictionary method for supporting comprehension of text containing the target words, but we do not know how much instruction is sufficient.

3. There is very limited evidence that direct teaching of word meanings, even long-term, multifaceted interventions of large numbers of words, can improve generalized comprehension.

4. There is currently no empirical evidence that instruction in one or two strategies for solving word meanings will impact generalized comprehension. However, studies that actively teach students to monitor their understanding of vocabulary and use multiple, flexible strategies for solving word meanings are a promising area for future research.

Next, we discuss each of these findings and its implications for practice and future research.

\section{Theme 1: Teaching Word Meanings Supports Text Comprehension}

The finding that teaching the meanings of words in a passage is an effective support for comprehension is consistent with those reported by Stahl and Fairbanks (1986) in their landmark meta-analysis. We examined a large number of studies of direct teaching on taught-word comprehension measures in this review, and the majority of these studies found positive, significant effects for the treatment. These findings offer clear implications for practice: Even limited vocabulary instruction (i.e., less than one minute per word) is better than no vocabulary instruction at all if the goal is to support students' comprehension of a particular text. Providing students with even brief explanations of word meanings prior to reading boosted passage comprehension compared with not receiving this instruction (e.g., Carney et al., 1984). Likewise, using technology to give students access to glosses (i.e., to provide basic information about word meanings) while reading online boosted comprehension and may be an efficient and practical strategy for supporting students’ reading (e.g., Türk \& Erçetin, 2014).

Text comprehension depends in part on understanding the meanings of the words in the text and on integrating their meanings into the development of a mental model of the text (Perfetti \& Stafura, 2014). Therefore, it is not surprising that even a small amount of information about the meaning of unfamiliar words in a text - and particularly about the specific meanings intended in the text - might give students a boost in their comprehension of a text containing the 
taught words. In light of this finding, it is particularly concerning that studies have repeatedly documented little vocabulary instruction in schools (Carlisle, Kelcey, \& Berebitsky, 2013; Scott, Jamieson-Noel, \& Asselin, 2003; Wright \& Neuman, 2014).

\section{Theme 2: Active Processing Matters, but How Much Active Processing Is Enough?}

Although brief attention to word meanings boosted comprehension compared with no vocabulary support at all, most of the studies included in this analysis showed that active processing of word meanings during instruction has a greater impact on comprehension than more passive approaches, such as being told the definitions of words. After almost 30 additional years of vocabulary research, this finding also affirms Stahl and Fairbanks's (1986) conclusions on depth of processing and aligns with Mezynski’s (1983) speed-of-access hypothesis and cognitiveprocessing theories (Bransford, Brown, \& Cocking, 1999), which focus on the active mental manipulation of word meanings to improve access to these meanings from memory.

Yet, there continue to be challenges in interpreting these findings in practice given the wide array of instructional approaches. Some studies involving multifaceted instruction spent a substantial amount of instructional time on each word, using numerous, intensive instructional methods, whereas other studies addressed active processing by including brief semantic mapping or asking students to briefly discuss a word or write a sentence to apply a word's meaning. Due to the broad range of instructional methods that showed positive effects and the variability in the outcome measures used to test these effects and comparison treatments, it is difficult to determine whether more extensive attention to active processing (i.e., longer duration, more instructional time dedicated to each word) supports comprehension of taught-word passages more effectively than interventions of more modest intensity.

Further complicating this issue is the ambiguity around retention. Within the studies of long-term vocabulary programs involving multifaceted instruction, taught-word comprehension posttests were often administered at the end of months-long interventions, whereas in many of the shorter interventions, comprehension assessments were administered shortly after students learned the meanings of words that would appear in the assessment passages. In general, both types of studies positively impacted taught-word comprehension, but it may be that the more intensive instructional methods support sustained impacts of the vocabulary intervention on comprehension. Three studies by Bos and colleagues (Bos \& Anders, 1990, 1992; Bos et al., 
1989) tested this question empirically by administering follow-up comprehension measures four to six weeks later. All three found that all active-processing conditions continued to have an advantage over conditions without active processing; yet, no differences among activeprocessing conditions were found. Therefore, future research must determine how much attention to active processing is sufficient to support comprehension of texts that will be read immediately compared with texts that students will encounter in the future.

Stahl (1990) argued that there are certain reader- and text-based factors that may require more extensive vocabulary instruction to support comprehension of a passage with new vocabulary: if the concept represented by the new word is not known by the student, if the proposition that the word is in is relatively important for comprehension of the entire passage, and if the context is nondirective or misdirective (i.e., making it difficult to figure out the word from context). In other cases, such as if the concept is familiar, if the word is relatively unimportant to the overall meaning of the passage, or if the context is directive, Stahl suggested that extensive instruction may not be needed. Yet, only one study (Wixson, 1986) examined word learning with attention to any of these nuances. In particular, Wixson found that teaching students the meanings of words that were central to a story improved students' comprehension of more central ideas in the text. This suggests that if the goal is to improve comprehension of a particular text, investing instructional time in words that are closest to the key ideas and themes might have the greatest payoff in terms of comprehension. However, in the current review, most studies taught general academic words without regard to the difficulty of the concepts or the role of the words in the passages. Also, in most cases, all words within a program received a similar instructional treatment. Instructional time is precious, and therefore future research must seek to understand the amount and type of instruction that should be provided for individual words relative to impact on comprehension.

Two outcomes of Stahl and Fairbanks's (1986) review that we were unable to examine systematically were their finding that more than one or two exposures to target words resulted in greater impacts on comprehension and their finding that definition plus contextual information is better for comprehension than either of these alone. All but two studies in the review (i.e., the studies of glosses) included more than one or two exposures to the target word. As such, there was limited variability. Also, only two studies in our review systematically manipulated the number of exposures to the target words, and both found benefits for many exposures (Beck et 
al., 1982; McKeown et al., 1983). Only one study directly compared a definition with a definition-plus-context condition (Stahl, 1983). In that study, both conditions had equivalent effects on the comprehension measure; however, both conditions involved students in actively processing the words' meanings. Future studies should consider whether these particular instructional features (i.e., exposures; definitions, contextual information, or both) remain the most important characteristics to consider in designing vocabulary instruction for authentic classroom contexts or whether the more nuanced approach suggested by Stahl (1990) in later work (i.e., which words should be taught, in which ways, for which comprehension goals) is more generative for supporting comprehension.

Another important consideration based on this study may be the age of the students. Although the majority of included studies focused on upper elementary students, in the two studies that focused only on kindergartners, multifaceted direct teaching of Tier 2 words did not improve students' listening comprehension of texts containing those words. Importantly, in one of these studies (Coyne et al., 2010), students who started with higher vocabulary scores at pretest scored higher on the posttest comprehension measure. This suggests that young students with more limited vocabulary knowledge may not yet be ready to benefit from the type of instruction typically provided in multifaceted vocabulary interventions. For example, it is possible that younger students may need support with more common, everyday (i.e., Tier 1) words that occur in text (Hiebert, 2005). Future research should consider students' developmental needs in designing vocabulary instruction.

Overall, these findings challenge the conventional wisdom that more time-consuming, multifaceted instruction is always more effective than less time-consuming instruction for taught-word comprehension. More research is needed to understand how a range of factorstype of word, type of text, the role of the new word in the text, word retention goals, particular comprehension/learning goals, and developmental learning needs-might be important for promoting effective and efficient taught-word comprehension. As Stahl (1990) pointed out, "extensive instruction may not be needed for all words in all situations. What is needed is a means for teachers to better estimate when words need extensive instruction and when less extensive instruction would be equally useful" (p. 3). 


\section{Theme 3: Limited Evidence That Teaching Word Meanings Improves Generalized Comprehension}

Although it is clear that vocabulary instruction can improve comprehension of a text containing taught words, the studies in this review do not give us a very clear picture about how we can move the needle on text comprehension more generally by supporting students' vocabulary development. Although correlational studies have documented a relationship between vocabulary knowledge and comprehension (e.g., Cunningham \& Stanovich, 1997), we found only two studies that were able to use direct teaching of word meanings as a mechanism for improving students' generalized comprehension. In 1987, Nagy and Herman argued that "it is highly unlikely that teaching individual word meanings could ever produce more than a very slight increase in general reading comprehension" (p. 31), and this prediction seems to have presaged the findings of much of the next 30 years of vocabulary research.

In most cases, even multifaceted, long-term direct teaching of a large number of word meanings did not impact students' generalized comprehension compared with no-treatment control groups. This is particularly discouraging because these interventions required an enormous investment of instructional time. Students typically acquired information about the instructed words and often performed better than no-treatment controls on taught-word comprehension measures; however, there was no far transfer to the generalized comprehension measures, even when hundreds of words were instructed in depth over a period as long as two years (e.g., Apthorp et al., 2012). This finding seems to support Nagy and colleagues' (e.g., Nagy $\&$ Anderson, 1984) contention that given the sheer number of words that students encounter in text, even very intensive and long-term direct instruction on a small subset of these words seems an unlikely strategy to make a dent in supporting generalized comprehension.

It is possible that impacts on generalized comprehension could be achieved in more longitudinal interventions. The amount and depth of vocabulary knowledge needed to impact generalized comprehension may take years of vocabulary instruction to develop. Yet, based on current evidence, it seems critical to consider whether these time-intensive interventions will provide an appropriate return on the instructional investment. When interventions spend anywhere from 15 minutes to almost an hour to teach an individual word, using hundreds of instructional hours over a school year, and fail to positively impact generalized comprehension, questions arise about whether there might be a better use for this precious instructional time. 
Future research should consider the trade-offs of devoting so much time to vocabulary instruction relative to other approaches to supporting students' comprehension.

Two studies were able to document impacts of direct teaching of word meanings on generalized comprehension. It is worth considering how these studies are distinct, particularly because several newer studies in this review that employed similar instructional methods as Beck et al. (1982) have been unable to replicate that study's positive findings on generalized comprehension. As we look at this study and at Nelson and Stage's (2007) study, which also found positive generalized comprehension effects, several features stand out. First, in both cases, the researchers focused on words that were both unknown and expected to appear in texts that students were likely to read in that school year, rather than selecting a set of general academic words. For example, Nelson and Stage focused on identifying challenging words that students were likely to encounter in grade-level texts, and Beck et al. selected words from curricular reading materials. Second, in both cases, words were grouped in semantically related sets (i.e., semantic categories in Beck et al.'s study, sets of four related words in Nelson and Stage's study). An additional, unique feature of Nelson and Stage's intervention is its focus on teaching polysemy. Researchers have found that polysemy is a likely cause of challenges for readers, particularly in discipline-specific texts where words have particular or uncommon meanings (Cervetti, Hiebert, Pearson, \& McClung, 2015). Yet, this was the only study in which the word selection and instructional methods specifically targeted this issue, and therefore additional studies focused on polysemy are needed. Together, these findings point to the need for further research on more targeted word selection strategies that carefully consider the ways that vocabulary in texts that students are likely to read might pose particular challenges to text comprehension.

Stahl and Fairbanks (1986) hypothesized that any positive effects of vocabulary teaching on generalized comprehension measures may not be due to the words that were directly taught but rather to other incidental effects of vocabulary instruction, such as greater interest in and attention to other words while students are reading. Another possibility is that direct teaching of word meanings may promote improved comprehension in texts containing that word, which in turn allows for incidental vocabulary learning. According to Nagy's (2005) reciprocal model of the relationship between vocabulary and comprehension, strong comprehenders are likely to gain new vocabulary incidentally as they read. There is also empirical evidence for the idea that text 
comprehension is a platform for learning new words (Barnes, Ginther, \& Cochran, 1989; Diakidoy, 1998). For example, Diakidoy found that sixth-grade students who had higher comprehension of a social studies text acquired more knowledge of low-frequency, target vocabulary word meanings from context than did students with poor comprehension of the text, independent of the students' breadth of prior word knowledge. Therefore, supporting students' vocabulary by teaching a set of target words may, in turn, boost comprehension of a text containing those words enough to enable students to learn untaught words in the text incidentally as they read. These incidentally learned words, in turn, may support future comprehension of texts containing those words. Additional research is needed to investigate these complexities.

Some have argued that the "generalized comprehension" construct should not be used in education because comprehension is genre-specific (Duke \& Roberts, 2010), discipline- or content-specific (Shanahan, Shanahan, \& Misischia, 2011), or even topic- or domain-specific (Hirsch, 2003; Recht \& Leslie, 1988). As such, teaching specific word meanings with the goal of improving comprehension of all texts may be an unrealistic goal. Yet, if words represent broader conceptual knowledge (i.e., the knowledge hypothesis; Anderson \& Freebody, 1981), it is possible that this conceptual knowledge might transfer to texts that require a similar knowledge base. Although we found studies that taught words during content area instruction and included passage comprehension measures (e.g., Cervetti, Barber, Dorph, Pearson, \& Goldschmidt, 2012), we could not disentangle vocabulary instruction from content area (i.e., knowledge-building) instructional methods in these studies and, therefore, could not include them in this analysis. Thus, the relationships among knowledge building, vocabulary instruction, and text comprehension need further study.

\section{Theme 4: No Evidence That Teaching One or Two Strategies Supports Generalized Comprehension}

Interventions that taught one or two strategies for figuring out the meanings of unknown words (e.g., morphological or context clues) did not show results on generalized comprehension measures, even compared with no-treatment controls. Although students typically learned the strategy or strategies that were the focus of the intervention (i.e., students who were taught to use context clues to solve unknown vocabulary improved at using context clues to figure out unknown vocabulary), these effects did not transfer to more global comprehension. 
One possible explanation for the lack of effects in these studies may be that longer term strategy interventions are necessary for further transfer effects. More studies examining longitudinal strategy instruction are needed. Another possibility suggested by the studies that we examined is that to impact comprehension, rather than learning a single strategy, students may need to be taught to self-monitor their understanding of word meanings and use multiple, flexible strategies for solving unknown word meanings in text. Studies that taught students to select their own words and to solve or study these words independently using multiple strategies showed promise for comprehension (Dole et al., 1995; Lubliner \& Smetana, 2005). Likewise, a study that taught students to engage in different types of semantic and syntactic analysis of texts also found positive impacts on generalized comprehension (Sampson et al., 1982). However, more evidence to support these ideas is needed, particularly because one of the two studies showing positive effects for multiple-strategies instruction involved a researcher-designed generalized comprehension measure rather than a validated, standardized measure. In particular, the promising studies focused on both procedural (i.e., how to use) and conditional (i.e., when to use) knowledge of a set of vocabulary strategies. However, this type of strategy instruction remains an area that requires further research.

\section{Limitations and Conclusions}

There are several limitations to this study. In our focus on comprehension, we underestimate the impact of the studies that we have examined. Many demonstrated student learning of vocabulary and student improvement in other linguistic knowledge (e.g., morphology). Knowing words is, of course, important for students beyond the goal of reading comprehension because vocabulary knowledge may support students in their oral participation in school (e.g., Wright \& Gotwals, in press) and also in their writing (e.g., Olinghouse \& Wilson, 2013). This study was a qualitative synthesis, which had the benefit of enabling us to consider patterns in instruction across the studies; however, we could only consider effects on comprehension as a yes/no variable. We could not consider the relative impact of different instructional methods as one could in a metaanalysis if there were enough studies in each category.

Also, we did not include dissertations or unpublished research because we were interested in methods that had been vetted by the peer review process, and therefore the included studies may reflect a publication bias. Interestingly, eight of the 15 studies with generalized comprehension measures in Elleman et al.'s (2009) meta-analysis were dissertations, yet we 
could not locate peer-reviewed versions of these studies. The most important limitation is that we were unable to look at the longitudinal impact of vocabulary instruction. The theory underlying direct vocabulary instruction is that this might, over time, build students' vocabulary repertoire enough to cause a positive spiral of improved comprehension, more reading, and greater incidental vocabulary acquisition during reading. It may be that none of the interventions that we analyzed were long enough to achieve these more distal effects. Likewise, Graves (2015) recommended more replete vocabulary programs that include a rich language environment, direct teaching of word meanings, strategy instruction, and supporting students' word consciousness (i.e., awareness that words are important). We found no studies that engaged in this more comprehensive instruction.

With these limitations, this review has identified important themes from this existing research that can inform vocabulary instruction with an eye to improving comprehension of texts. It has also identified many issues that are unresolved due to inadequate or conflicting evidence in spite of 50 years and dozens of studies. Particularly lacking is our understanding about how to develop economical and effective interventions for improving students' generalized comprehension through vocabulary building. In addition, there is much to be learned about prereading vocabulary instruction and its longer term impacts. We hope that the research community will redouble its efforts to address these pressing questions.

\section{$\underline{\text { Notes }}$}

We thank the following doctoral students for their work as research assistants on this project: HyeJin Hwang, Andy Kwok, and Donald McClure.

${ }^{1}$ Note that some studies were included in both the taught-word and generalized comprehension analyses if they included both types of measures.

\section{$\underline{\text { References }}$}

References marked with an asterisk indicate studies included in the meta-analysis. Anderson, R.C., \& Freebody, P. (1981). Vocabulary knowledge. In J.T. Guthrie (Ed.), Comprehension and teaching: Research reviews (pp. 77-117). Newark, DE: International Reading Association. 
*Apthorp, H.S. (2006). Effects of a supplemental vocabulary program in third-grade reading/language arts. The Journal of Educational Research, 100(2), 67-79. doi:10.3200/JOER.100.2.67-79

*Apthorp, H., Randel, B., Cherasaro, T., Clark, T., McKeown, M., \& Beck, I. (2012). Effects of a supplemental vocabulary program on word knowledge and passage comprehension. Journal of Research on Educational Effectiveness, 5(2), 160-188. doi:10.1080/19345747.2012.660240

Barnes, J.A., Ginther, D.W., \& Cochran, S.W. (1989). Schema and purpose in reading comprehension and learning vocabulary from context. Reading Research and Instruction, $28(2), 16-28$.

Baumann, J.F. (2005). Vocabulary-comprehension relationships. In B. Maloch, J.V. Hoffman, D.L. Schallert, C.M. Fairbanks, \& J. Worthy (Eds.), 54th yearbook of the National Reading Conference (pp. 117-131). Oak Creek, WI: National Reading Conference.

*Baumann, J.F., Edwards, E.C., Boland, E.M., Olejnik, S., \& Kame'enui, E.J. (2003).

Vocabulary tricks: Effects of instruction in morphology and context on fifth-grade students' ability to derive and infer word meanings. American Educational Research Journal, 40(2), 447-494. doi:10.3102/00028312040002447

*Baumann, J.F., Edwards, E.C., Font, G., Tereshinski, C.A., Kame'enui, E.J., \& Olejnik, S. (2002). Teaching morphemic and contextual analysis to fifth-grade students. Reading Research Quarterly, 37(2), 150-176. doi:10.1598/RRQ.37.2.3

Baumann, J.F., Kame'enui, E.J., \& Ash, G.E. (2003). Research on vocabulary instruction: Voltaire redux. In J. Flood, D. Lapp, J.R. Squire, \& J.M. Jenson (Eds.), Handbook of research on teaching the language arts (pp. 752-785). Mahwah, NJ: Erlbaum.

Beck, I.L., \& McKeown, M.G. (1991). Conditions of vocabulary acquisition. In R. Barr, M.L. Kamil, P.B. Mosenthal, \& P.D. Pearson (Eds.), Handbook of reading research (Vol. 2, pp. 789-814). Mahwah, NJ: Erlbaum.

Beck, I.L., \& McKeown, M.G. (2007). Increasing young low-income children's oral vocabulary repertoires through rich and focused instruction. The Elementary School Journal, 107(3), 251-271. doi:10.1086/511706

Beck, I.L., McKeown, M.G., \& Kucan, L. (2013). Bringing words to life: Robust vocabulary instruction. New York, NY: Guilford.

This article is protected by copyright. All rights reserved 
*Beck, I.L., Perfetti, C.A., \& McKeown, M.G. (1982). Effects of long-term vocabulary instruction on lexical access and reading comprehension. Journal of Educational Psychology, 74(4), 506-521. doi:10.1037/0022-0663.74.4.506

Biemiller, A., \& Boote, C. (2006). An effective method for building meaning vocabulary in primary grades. Journal of Educational Psychology, 98(1), 44-62. doi:10.1037/00220663.98.1.44

Blachowicz, C.L.Z., \& Fisher, P.J. (2000). Vocabulary instruction. In M.L. Kamil, P.B. Mosenthal, P.D. Pearson, \& R. Barr (Eds.), Handbook of reading research (Vol. 3, pp. 503-523). Mahwah, NJ: Erlbaum.

*Bos, C.S., \& Anders, P.L. (1990). Effects of interactive vocabulary instruction on the vocabulary learning and reading comprehension of junior-high learning disabled students. Learning Disability Quarterly, 13(1), 31-42. doi:10.2307/1510390

*Bos, C.S., \& Anders, P.L. (1992). Using interactive teaching and learning strategies to promote text comprehension and content learning for students with learning disabilities. International Journal of Disability Development and Education, 39(3), 225-238. doi:10.1080/0156655920390305

*Bos, C.S., Anders, P.L., Filip, D., \& Jaffe, L.E. (1989). The effects of an interactive instructional strategy for enhancing reading comprehension and content area learning for students with learning disabilities. Journal of Learning Disabilities, 22(6), 384-390. doi:10.1177/002221948902200611

Bransford, J.D., Brown, A.L., \& Cocking, R.R. (1999). How people learn: Brain, mind, experience, and school. Washington, DC: National Academy Press.

Carlisle, J.F., Kelcey, B., \& Berebitsky, D. (2013). Teachers's support of students' vocabulary learning during literacy instruction in high poverty elementary schools. American Educational Research Journal, 50(6), 1360-1391. doi:10.3102/0002831213492844

*Carney, J.J., Anderson, D., Blackburn, C., \& Blessing, D. (1984). Preteaching vocabulary and the comprehension of social studies materials by elementary school children. Social Education, 48(3), 195-196.

Catts, H.W., Adlof, S.M., \& Weismer, S.E. (2006). Language deficits in poor comprehenders: A case for the simple view of reading. Journal of Speech, Language, and Hearing Research, 49(2), 278-293. doi:10.1044/1092-4388(2006/023) 
Cervetti, G.N., Barber, J., Dorph, R., Pearson, P.D., \& Goldschmidt, P.G. (2012). The impact of an integrated approach to science and literacy in elementary school classrooms. Journal of Research in Science Teaching, 49(5), 631-658. doi:10.1002/tea.21015

Cervetti, G.N., Hiebert, E.H., Pearson, P.D., \& McClung, N.A. (2015). Factors that influence the difficulty of science words. Journal of Literacy Research, 47(2), 153-185. doi:10.1177/1086296X15615363

Christian, K., Morrison, F.J., Frazier, J.A., \& Massetti, G. (2000). Specificity in the nature and timing of cognitive growth in kindergarten and first grade. Journal of Cognition and Development, 1(4), 429-448. doi:10.1207/S15327647JCD0104_04

Coxhead, A. (2000). A new academic word list. TESOL Quarterly, 34(2), 213-238. doi:10.2307/3587951

*Coyne, M.D., McCoach, D.B., Loftus, S., Zipoli, R., Ruby, M., Crevecoeur, Y.C., \& Kapp, S. (2010). Direct and extended instruction in kindergarten: Investigating transfer effects. Journal of Research on Educational Effectiveness, 3(2), 93-120.

doi:10.1080/19345741003592410

Crevecoeur, Y.C., Coyne, M.D., \& McCoach, D.B. (2014). English language learners and English-only learners' response to direct vocabulary instruction. Reading \& Writing Quarterly, 30(1), 51-78. doi:10.1080/10573569.2013.758943

Cunningham, A.E., \& Stanovich, K.E. (1997). Early reading acquisition and its relation to reading experience and ability 10 years later. Developmental Psychology, 33(6), 934945. doi:10.1037/0012-1649.33.6.934

Dale, E., \& O'Rourke, J. (1981). The living word vocabulary: A national vocabulary inventory. Chicago, IL: World Book-Childcraft International.

Diakidoy, L.N. (1998). The role of reading comprehension in word meaning acquisition during reading. European Journal of Psychology of Education, 13(2), 131-154. doi:10.1007/BF03173086

*Dole, J.A., Sloan, C., \& Trathen, W. (1995). Teaching vocabulary within the context of literature. Journal of Reading, 38(6), 452-460.

Duke, N.K., \& Roberts, K.L. (2010). The genre-specific nature of reading comprehension. In D. Wyse, R. Andrews, \& J. Hoffman (Eds.), The international handbook of English, language and literacy teaching (pp. 501-520). New York, NY: Guilford. 
Elleman, A.M., Lindo, E.J., Morphy, P., \& Compton, D.L. (2009). The impact of vocabulary instruction on passage-level comprehension of school-age children: A meta-analysis. Journal of Research on Educational Effectiveness, 2(1), 1-44. doi:10.1080/19345740802539200

Ford-Connors, E., \& Paratore, J.R. (2015). Vocabulary instruction in fifth grade and beyond: Sources of word learning and productive contexts for development. Review of Educational Research, 85(1), 50-91. doi:10.3102/0034654314540943

Graves, M.F. (2006). The vocabulary book: Learning and instruction. New York, NY: Teachers College Press.

Graves, M.F. (2015). Building a vocabulary program that really could make a significant contribution to students becoming college and career ready. In P.D. Pearson \& E.H. Hiebert (Eds.), Research-based practices for Common Core literacy (pp. 123-142). New York, NY: Teachers College Press.

*Greene Brabham, E., \& Lynch-Brown, C. (2002). Effects of teachers' reading-aloud styles on vocabulary acquisition and comprehension of students in the early elementary grades. Journal of Educational Psychology, 94(3), 465-473. doi:10.1037/0022-0663.94.3.465

*Hafner, L.E. (1965). A one-month experiment in teaching context aids in fifth grade. The Journal of Educational Research, 58(10), 472-474. doi:10.1080/00220671.1965.10883279

*Hawkins, R.O., Musti-Rao, S., Hale, A.D., McGuire, S., \& Hailley, J. (2010). Examining listening previewing as a classwide strategy to promote reading comprehension and vocabulary. Psychology in the Schools, 47(9), 903-916. doi:10.1002/pits.20513

Hiebert, E.H. (2005). In pursuit of an effective, efficient vocabulary curriculum for elementary students. In E.H. Hiebert \& M.L. Kamil (Eds.), Teaching and learning vocabulary (pp. 243-263). Mahwah, NJ: Erlbaum.

Hirsch, E.D. (2003). Reading comprehension requires knowledge of words and the world. American Educator, 27(1), 10-13, 16-22, 28-29, 48.

Hsu, C.-K., Hwang, G.-J., Chang, Y.-T., \& Chang, C.-K. (2013). Effects of video caption modes on English listening comprehension and vocabulary acquisition using handheld devices. Journal of Educational Technology \& Society, 16(1), 403-414. 
Jackson, J.R., \& Dizney, H. (1963). Intensive vocabulary training. Journal of Developmental Reading, 6(4), 221-229.

*Kame'enui, E.J., Carnine, D.W., \& Freschi, R. (1982). Effects of text construction and instructional procedures for teaching word meanings on comprehension and recall. Reading Research Quarterly, 17(3), 367-388. doi:10.2307/747525

Kieffer, M.J., \& Lesaux, N.K. (2012). Effects of academic language instruction on relational and syntactic aspects of morphological awareness for sixth graders from linguistically diverse backgrounds. The Elementary School Journal, 112(3), 519-545. doi:10.1086/663299

Korat, O., \& Shamir, A. (2012). Direct and indirect teaching: Using e-books for supporting vocabulary, word reading, and story comprehension for young children. Journal of Educational Computing Research, 46(2), 135-152. doi:10.2190/EC.46.2.b

*Lesaux, N.K., Kieffer, M.J., Faller, S.E., \& Kelley, J.G. (2010). The effectiveness and ease of implementation of an academic vocabulary intervention for linguistically diverse students in urban middle schools. Reading Research Quarterly, 45(2), 196-228. doi:10.1598/RRQ.45.2.3

*Lesaux, N.K., Kieffer, M.J., Kelley, J.G., \& Harris, J.R. (2014). Effects of academic vocabulary instruction for linguistically diverse adolescents: Evidence from a randomized field trial. American Educational Research Journal, 51(6), 1159-1194. doi:10.3102/0002831214532165

*Levin, J.R., Levin, M.E., Glasman, L.D., \& Nordwall, M.B. (1992). Mnemonic vocabulary instruction: Additional effectiveness evidence. Contemporary Educational Psychology, 17(2), 156-174. doi:10.1016/0361-476X(92)90056-5

*Lubliner, S., \& Smetana, L. (2005). The effects of comprehensive vocabulary instruction on Title I students' metacognitive word-learning skills and reading comprehension. Journal of Literacy Research, 37(2), 163-200. doi:10.1207/s15548430j1r3702_3

Marulis, L.M., \& Neuman, S.B. (2010). The effects of vocabulary intervention on young children's word learning: A meta-analysis. Review of Educational Research, 80(3), 300335. doi:10.3102/0034654310377087

*McKeown, M.G., \& Beck, I.L. (2014). Effects of vocabulary instruction on measures of language processing: Comparing two approaches. Early Childhood Research Quarterly, 29(4), 520-530. doi:10.1016/j.ecresq.2014.06.002 
*McKeown, M.G., Beck, I.L., Omanson, R.C., \& Perfetti, C.A. (1983). The effects of long-term vocabulary instruction on reading comprehension: A replication. Journal of Literacy Research, 15(1), 3-18. doi:10.1080/10862968309547474

*McKeown, M.G., Beck, I.L., Omanson, R.C., \& Pople, M.T. (1985). Some effects of the nature and frequency of vocabulary instruction on the knowledge and use of words. Reading Research Quarterly, 20(5), 522-535. doi:10.2307/747940

*Medo, M.A., \& Ryder, R.J. (1993). The effects of vocabulary instruction on readers' ability to make causal connections. Literacy Research and Instruction, 33(2), 119-134.

Mezynski, K. (1983). Issues concerning the acquisition of knowledge: Effects of vocabulary training on reading comprehension. Review of Educational Research, 53(2), 253-279. doi:10.3102/00346543053002253

Miles, M.B., \& Huberman, A.M. (1994). Qualitative data analysis: An expanded sourcebook. Thousand Oaks, CA: Sage.

Nagy, W.E. (2005). Why instruction needs to be long-term and comprehensive. In E.H. Hiebert \& M.L. Kamil (Eds.), Teaching and learning vocabulary: Bringing research to practice (pp. 27-44). Chicago, IL: Routledge.

Nagy, W.E., \& Anderson, R.C. (1984). How many words are there in printed school English? Reading Research Quarterly, 19(3), 304-330. doi:10.2307/747823

Nagy, W.E., \& Herman, P.A. (1987). Breadth and depth of vocabulary knowledge: Implications for acquisition and instruction. In M.G. McKeown \& M.G. Curtis (Eds.), The nature of vocabulary acquisition (pp. 19-35). Mahwah, NJ: Erlbaum.

Nagy, W.E., \& Hiebert, E.H. (2010). Toward a theory of word selection. In M.L. Kamil, P.D. Pearson, E.B. Moje, \& P.P. Afflerbach (Eds.), Handbook of reading research (Vol. 4, pp. 388-404). New York, NY: Routledge.

*Nash, H., \& Snowling, M. (2006). Teaching new words to children with poor existing vocabulary knowledge: A controlled evaluation of the definition and context methods. International Journal of Language \& Communication Disorders, 41(3), 335-354. doi:10.1080/13682820600602295

National Governors Association Center for Best Practices \& Council of Chief State School Officers. (2010). Common Core State Standards for English language arts and literacy in history/social studies, science, and technical subjects. Washington, DC: Authors.

This article is protected by copyright. All rights reserved 
National Institute for Literacy. (2008). Developing early literacy: Report of the National Early Literacy Panel. Jessup, MD: Author.

National Institute of Child Health and Human Development. (2000). Report of the National Reading Panel. Teaching children to read: An evidence-based assessment of the scientific research literature on reading and its implications for reading instruction (NIH Publication No. 00-4769). Washington, DC: U.S. Government Printing Office.

*Nelson, J.R., \& Stage, S.A. (2007). Fostering the development of vocabulary knowledge and reading comprehension though contextually-based multiple meaning vocabulary instruction. Education \& Treatment of Children, 30(1), 1-22. doi:10.1353/etc.2007.0003

Olinghouse, N.G., \& Wilson, J. (2013). The relationship between vocabulary and writing quality in three genres. Reading and Writing, 26(1), 45-65. doi:10.1007/s11145-012-9392-5

*Pany, D., Jenkins, J.R., \& Schreck, J. (1982). Vocabulary instruction: Effects on word knowledge and reading comprehension. Learning Disability Quarterly, 5(3), 202-215. doi: $10.2307 / 1510288$

Pearson, P.D., \& Hamm, D.N. (2005). The assessment of reading comprehension: A review of practices_past, present, and future. In S.G. Paris \& S.A. Stahl (Eds.), Children's reading comprehension and assessment (pp. 13-69). Mahwah, NJ: Erlbaum.

Perfetti, C., \& Stafura, J. (2014). Word knowledge in a theory of reading comprehension. Scientific Studies of Reading, 18(1), 22-37. doi:10.1080/10888438.2013.827687

RAND Reading Study Group. (2002). Reading for understanding: Toward an R\&D program in reading comprehension. Santa Monica, CA: RAND.

Recht, D.R., \& Leslie, L. (1988). Effect of prior knowledge on good and poor readers' memory of text. Journal of Educational Psychology, 80(1), 16-20. doi:10.1037/00220663.80 .1 .16

*Reinking, D., \& Rickman, S.S. (1990). The effects of computer-mediated texts on the vocabulary learning and comprehension of intermediate-grade readers. Journal of Literacy Research, 22(4), 395-411. doi:10.1080/10862969009547720

Ricketts, J., Nation, K., \& Bishop, D.V.M. (2007). Vocabulary is important for some, but not all reading skills. Scientific Studies of Reading, 11(3), 235-257. doi:10.1080/10888430701344306 
*Sampson, M.R., Valmont, W.J., \& Van Allen, R. (1982). The effects of instructional cloze on the comprehension, vocabulary, and divergent production of third-grade students. Reading Research Quarterly, 17(3), 389-399. doi:10.2307/747526

Scott, J.A., Jamieson-Noel, D., \& Asselin, M. (2003). Vocabulary instruction throughout the day in 23 Canadian upper-elementary classrooms. The Elementary School Journal, 103(3), 269-286. doi:10.1086/499726

*Seifert, K., \& Espin, C. (2012). Improving reading of science text for secondary students with learning disabilities: Effects of text reading, vocabulary learning, and combined approaches to instruction. Learning Disability Quarterly, 35(4), 236-247. doi:10.1177/0731948712444275

Sénéchal, M., Ouellette, G., \& Rodney, D. (2006). The misunderstood giant: On the predictive role of early vocabulary to future reading. In D.K. Dickinson \& S.B. Neuman (Eds.), Handbook of early literacy research (Vol. 2, pp. 173-182). New York, NY: Guilford.

Shanahan, C., Shanahan, T., \& Misischia, C. (2011). Analysis of expert readers in three disciplines: History, mathematics, and chemistry. Journal of Literacy Research, 43(4), 393-429. doi:10.1177/1086296X11424071

Silverman, R. (2007). A comparison of three methods of vocabulary instruction during read-alouds in kindergarten. The Elementary School Journal, 108(2), 97-113. doi:10.1086/525549

*Simmons, D., Hairrell, A., Edmonds, M., Vaughn, S., Larsen, R., Wilson, V., ... Byrns, G. (2010). A comparison of multiple strategy methods: Effects on fourth-grade students' general and content-specific reading comprehension and vocabulary development. Journal of Research on Educational Effectiveness, 3(2), 121-156. doi:10.1080/19345741003596890

*Stahl, S. (1983). Differential word knowledge and reading comprehension. Journal of Reading Behavior, 15(4), 33-47.

Stahl, S. (1990). Beyond the instrumentalist hypothesis: Some relationships between word meanings and comprehension (Technical Report No. 505). Urbana: Center of the Study of Reading, University of Illinois at Urbana-Champaign. 
Stahl, S.A., \& Fairbanks, M.M. (1986). The effects of vocabulary instruction: A model-based meta-analysis. Review of Educational Research, 56(1), 72-110. doi:10.3102/00346543056001072

Stahl, S.A., Hare, V.C., Sinatra, R., \& Gregory, J.F. (1991). Defining the role of prior knowledge and vocabulary in reading comprehension: The retiring of number 41. Journal of Reading Behavior, 23(4), 487-508.

Stanovich, K.E. (1986). Matthew effects in reading: Some consequences of individual differences in the acquisition of literacy. Reading Research Quarterly, 21(4), 360-407. doi:10.1598/RRQ.21.4.1

Taboada, A., \& Rutherford, V. (2011). Developing reading comprehension and academic vocabulary for English language learners through science content: A formative experiment. Reading Psychology, 32(2), 113-157. doi:10.1080/02702711003604468

Thorndike, E.L. (1917). Reading as reasoning: A study of mistakes in paragraph reading. Journal of Educational Psychology, 8(6), 323-332. doi:10.1037/h0075325

*Tomesen, M., \& Aarnoutse, C. (1998). Effects of an instructional programme for deriving word meanings. Educational Studies, 24(1), 107-128. doi:10.1080/0305569980240108

*Tuinman, J.J., \& Brady, M.E. (1974). How does vocabulary account for variance on reading comprehension tests? A preliminary instructional analysis. In P.L. Nacke (Ed.), 23rd yearbook of the National Reading Conference (pp. 176-184). Clemson, SC: National Reading Conference.

*Türk, E., \& Erçetin, G. (2014). Effects of interactive versus simultaneous display of multimedia glosses on L2 reading comprehension and incidental vocabulary learning. Computer Assisted Language Learning, 27(1), 1-25. doi:10.1080/09588221.2012.692384

*Wixson, K.K. (1986). Vocabulary instruction and children's comprehension of basal stories. Reading Research Quarterly, 21(3), 317-329. doi:10.2307/747712

Wright, T.S., \& Gotwals, A.W. (in press). Supporting kindergartners' science talk in the context of an integrated science and disciplinary literacy curriculum. The Elementary School Journal.

Wright, T.S., \& Neuman, S.B. (2014). Paucity and disparity in kindergarten oral vocabulary instruction. Journal of Literacy Research, 46(3), 330-357. doi:10.1177/1086296X14551474 
Zeno, W.M., Ivens, S.H., Millard, R.T., \& Duvvuri, R. (1995). The educator's word frequency guide. New York, NY: Touchstone Applied Science.

*Zipke, M., Ehri, L.C., \& Cairns, H.S. (2009). Using semantic ambiguity instruction to improve third graders' metalinguistic awareness and reading comprehension: An experimental study. Reading Research Quarterly, 44(3), 300-321. doi:10.1598/RRQ.44.3.4

Submitted January 14, 2016

Final revision received July 7, 2016

Accepted July 12, 2016

[COMP: Please set the authors' names per RRQ's design.]

TANYA S. WRIGHT (corresponding author) is an assistant professor in the Department of Teacher Education at Michigan State University, East Lansing, USA; e-mail tswright@msu.edu.

GINA N. CERVETTI is an associate professor in the School of Education at the University of Michigan, Ann Arbor, USA; e-mail cervetti@umich.edu.

[Query: Please feel free to add another sentence to both author blurbs (e.g., research interests).]

Supporting Information

Additional supporting information may be found in the online version of this article:

- Appendix: Descriptions of the Included Studies

TABLE 1

Inclusion Criteria Across Three Reviews

\begin{tabular}{|l|l|l|l|l|c|}
\hline Review & $\begin{array}{l}\text { Study } \\
\text { years }\end{array}$ & Participants & Search & Outcome & $\begin{array}{c}\text { Total } \\
\text { number } \\
\text { of studies }\end{array}$ \\
\hline $\begin{array}{l}\text { Stahl, S.A., \& Fairbanks, M.M. (1986). The } \\
\text { effects of vocabulary instruction: A model- } \\
\text { based meta-analysis. Review of } \\
\text { Educational Research, 56(1), 72-110. }\end{array}$ & $\begin{array}{l}1932- \\
1985\end{array}$ & $\begin{array}{l}\text { All (grade 1- } \\
\text { college) }\end{array}$ & $\begin{array}{l}\text { ERIC search, } \\
\text { including } \\
\text { dissertations }\end{array}$ & $\begin{array}{l}\text { Any } \\
\text { comprehension } \\
\text { outcome, } \\
\text { including cloze }\end{array}$ & 52 \\
\hline $\begin{array}{l}\text { Elleman, A.M., Lindo, E.J., Morphy, P., \& } \\
\text { Compton, D.L. (2009). The impact of }\end{array}$ & $\begin{array}{l}1961- \\
2006\end{array}$ & Pre-K-12 & $\begin{array}{l}\text { Multiple } \\
\text { databases, }\end{array}$ & $\begin{array}{l}\text { Passage } \\
\text { comprehension }\end{array}$ & 37 \\
\hline
\end{tabular}




\begin{tabular}{|l|l|l|l|l|l|}
\hline $\begin{array}{l}\text { vocabulary instruction on passage-level } \\
\text { comprehension of school-age children: A } \\
\text { meta-analysis. Journal of Research on } \\
\text { Educational Effectiveness, 2(1), 1-44. }\end{array}$ & & $\begin{array}{l}\text { including } \\
\text { dissertations }\end{array}$ & & \\
\hline Current study & $\begin{array}{l}1965- \\
2015\end{array}$ & Pre-K-12 & $\begin{array}{l}\text { ERIC search, } \\
\text { peer- } \\
\text { reviewed } \\
\text { only }\end{array}$ & $\begin{array}{l}\text { Passage } \\
\text { comprehension }\end{array}$ & 36 \\
\hline
\end{tabular}

Note. We reviewed all studies contained in Stahl and Fairbanks's and Elleman et al.'s reviews. The earliest study that met the inclusion criteria for the current study was published in 1965.

TABLE 2

Studies of Direct Teaching on Comprehension of Passages With Embedded Taught Words

\begin{tabular}{|c|c|c|c|}
\hline Study & $\begin{array}{l}\text { Duration of } \\
\text { intervention }\end{array}$ & $\begin{array}{l}\text { Minutes of } \\
\text { instruction } \\
\text { per word }\end{array}$ & $\begin{array}{l}\text { Effects on } \\
\text { comprehension }\end{array}$ \\
\hline $\begin{array}{l}\text { Hawkins, R.O., Musti-Rao, S., Hale, A.D., McGuire, S., \& Hailley, } \\
\text { J. (2010). Examining listening previewing as a classwide strategy } \\
\text { to promote reading comprehension and vocabulary. Psychology in } \\
\text { the Schools, } 47(9), 903-916 .\end{array}$ & Brief & $<1^{a}$ & Yes \\
\hline $\begin{array}{l}\text { Kame'enui, E.J., Carnine, D.W., \& Freschi, R. (1982). Effects of } \\
\text { text construction and instructional procedures for teaching word } \\
\text { meanings on comprehension and recall. Reading Research } \\
\text { Quarterly, 17(3), 367-388. }\end{array}$ & Brief & $<1^{a}$ & Yes \\
\hline $\begin{array}{l}\text { Reinking, D., \& Rickman, S.S. (1990). The effects of computer- } \\
\text { mediated texts on the vocabulary learning and comprehension of } \\
\text { intermediate-grade readers. Journal of Literacy Research, 22(4), } \\
\text { 395-411. }\end{array}$ & Brief & $<1^{a}$ & Yes \\
\hline $\begin{array}{l}\text { Türk, E., \& Erçetin, G. (2014). Effects of interactive versus } \\
\text { simultaneous display of multimedia glosses on L2 reading } \\
\text { comprehension and incidental vocabulary learning. Computer } \\
\text { Assisted Language Learning, 27(1), 1-25. }\end{array}$ & Brief & $<1^{a}$ & Yes \\
\hline $\begin{array}{l}\text { Stahl, S. (1983). Differential word knowledge and reading } \\
\text { comprehension. Journal of Reading Behavior, 15(4), 33-47. }\end{array}$ & Brief & $2-3$ & Yes \\
\hline $\begin{array}{l}\text { Greene Brabham, E., \& Lynch-Brown, C. (2002). Effects of } \\
\text { teachers' reading-aloud styles on vocabulary acquisition and }\end{array}$ & Brief & 4.5 & Yes \\
\hline
\end{tabular}

This article is protected by copyright. All rights reserved 


\begin{tabular}{|c|c|c|c|}
\hline $\begin{array}{l}\text { comprehension of students in the early elementary grades. } \\
\text { Journal of Educational Psychology, 94(3), 465-473. }\end{array}$ & & & \\
\hline $\begin{array}{l}\text { Wixson, K.K. (1986). Vocabulary instruction and children's } \\
\text { comprehension of basal stories. Reading Research Quarterly, } \\
21(3), 317-329 .\end{array}$ & Brief & 6 & Yes \\
\hline $\begin{array}{l}\text { Pany, D., Jenkins, J.R., \& Schreck, J. (1982). Vocabulary } \\
\text { instruction: Effects on word knowledge and reading } \\
\text { comprehension. Learning Disability Quarterly, 5(3), 202-215. }\end{array}$ & Brief & $2-10$ & Yes \\
\hline $\begin{array}{l}\text { Carney, J.J., Anderson, D., Blackburn, C., \& Blessing, D. (1984). } \\
\text { Preteaching vocabulary and the comprehension of social studies } \\
\text { materials by elementary school children. Social Education, 48(3), } \\
\text { 195-196. }\end{array}$ & Brief & 10 & Yes \\
\hline $\begin{array}{l}\text { Bos, C.S., Anders, P.L., Filip, D., \& Jaffe, L.E. (1989). The effects } \\
\text { of an interactive instructional strategy for enhancing reading } \\
\text { comprehension and content area learning for students with } \\
\text { learning disabilities. Journal of Learning Disabilities, 22(6), 384- } \\
390 .\end{array}$ & Brief & 10 & Yes \\
\hline $\begin{array}{l}\text { McKeown, M.G., Beck, I.L., Omanson, R.C., \& Pople, M.T. (1985). } \\
\text { Some effects of the nature and frequency of vocabulary instruction } \\
\text { on the knowledge and use of words. Reading Research Quarterly, } \\
20(5), 522-535 .\end{array}$ & Brief & 15 & Yes \\
\hline $\begin{array}{l}\text { Nash, H., \& Snowling, M. (2006). Teaching new words to children } \\
\text { with poor existing vocabulary knowledge: A controlled evaluation } \\
\text { of the definition and context methods. International Journal of } \\
\text { Language \& Communication Disorders, 41(3), 335-354. }\end{array}$ & Brief & 15 & Yes \\
\hline $\begin{array}{l}\text { Bos, C.S., \& Anders, P.L. (1990). Effects of interactive vocabulary } \\
\text { instruction on the vocabulary learning and reading comprehension } \\
\text { of junior-high learning disabled students. Learning Disability } \\
\text { Quarterly, 13(1), 31-42. }\end{array}$ & Brief & 20 & Yes \\
\hline $\begin{array}{l}\text { Medo, M.A., \& Ryder, R.J. (1993). The effects of vocabulary } \\
\text { instruction on readers' ability to make causal connections. Literacy } \\
\text { Research and Instruction, 33(2), 119-134. }\end{array}$ & Brief & $\begin{array}{l}\text { Could not } \\
\text { calculate }^{b}\end{array}$ & Yes \\
\hline $\begin{array}{l}\text { Bos, C.S., \& Anders, P.L. (1992). Using interactive teaching and } \\
\text { learning strategies to promote text comprehension and content } \\
\text { learning for students with learning disabilities. International Journal } \\
\text { of Disability Development and Education, 39(3), 225-238. }\end{array}$ & Brief & $\begin{array}{l}\text { Could not } \\
\text { calculate }^{b}\end{array}$ & Yes \\
\hline Apthorp, H., Randel, B., Cherasaro, T., Clark, T., McKeown, M., \& & Long-term & $6-17$ & Yes \\
\hline
\end{tabular}




\begin{tabular}{|c|c|c|c|}
\hline $\begin{array}{l}\text { Beck, I. (2012). Effects of a supplemental vocabulary program on } \\
\text { word knowledge and passage comprehension. Journal of } \\
\text { Research on Educational Effectiveness, 5(2), 160-188. }\end{array}$ & & & \\
\hline $\begin{array}{l}\text { Beck, I.L., Perfetti, C.A., \& McKeown, M.G. (1982). Effects of long- } \\
\text { term vocabulary instruction on lexical access and reading } \\
\text { comprehension. Journal of Educational Psychology, 74(4), 506- } \\
521 .\end{array}$ & Long-term & 22 & Yes \\
\hline $\begin{array}{l}\text { McKeown, M.G., Beck, I.L., Omanson, R.C., \& Perfetti, C.A. } \\
\text { (1983). The effects of long-term vocabulary instruction on reading } \\
\text { comprehension: A replication. Journal of Literacy Research, 15(1), } \\
\text { 3-18. }\end{array}$ & Long-term & 22 & Yes \\
\hline $\begin{array}{l}\text { Lesaux, N.K., Kieffer, M.J., Kelley, J.G., \& Harris, J.R. (2014). } \\
\text { Effects of academic vocabulary instruction for linguistically diverse } \\
\text { adolescents: Evidence from a randomized field trial. American } \\
\text { Educational Research Journal, 51(6), 1159-1194. }\end{array}$ & Long-term & 59 & Yes \\
\hline $\begin{array}{l}\text { McKeown, M.G., \& Beck, I.L. (2014). Effects of vocabulary } \\
\text { instruction on measures of language processing: Comparing two } \\
\text { approaches. Early Childhood Research Quarterly, 29(4), 520-530. }\end{array}$ & Brief & $\begin{array}{l}\text { Could not } \\
\text { calculate }^{\text {b }}\end{array}$ & No \\
\hline $\begin{array}{l}\text { Seifert, K., \& Espin, C. (2012). Improving reading of science text } \\
\text { for secondary students with learning disabilities: Effects of text } \\
\text { reading, vocabulary learning, and combined approaches to } \\
\text { instruction. Learning Disability Quarterly, 35(4), 236-247. }\end{array}$ & Brief & 12 & No \\
\hline $\begin{array}{l}\text { Tuinman, J.J., \& Brady, M.E. (1974). How does vocabulary } \\
\text { account for variance on reading comprehension tests? A } \\
\text { preliminary instructional analysis. In P.L. Nacke (Ed.), 23rd } \\
\text { yearbook of the National Reading Conference (pp. 176-184). } \\
\text { Clemson, SC: National Reading Conference. }\end{array}$ & Brief & 10 & No \\
\hline $\begin{array}{l}\text { Coyne, M.D., McCoach, D.B., Loftus, S., Zipoli, R., Ruby, M., } \\
\text { Crevecoeur, Y.C., \& Kapp, S. (2010). Direct and extended } \\
\text { instruction in kindergarten: Investigating transfer effects. Journal of } \\
\text { Research on Educational Effectiveness, 3(2), 93-120. }\end{array}$ & Long-term & 20 & No \\
\hline
\end{tabular}

${ }^{\mathrm{a}}$ Time not provided in the report, but we were able to estimate based on the procedures provided. ${ }^{\mathrm{b}}$ Time not provided in the report, and we were unable to estimate based on the procedures provided.

[COMP: Please hang turnovers in lists and keep the text in columns 2 and 3 aligned across as shown.]

\section{TABLE 3}

This article is protected by copyright. All rights reserved 
Studies Comparing Multiple Methods for Direct Teaching of Word Meanings on Taught-Word Comprehension Outcomes

\begin{tabular}{|c|c|c|}
\hline Study & Vocabulary interventions & $\begin{array}{l}\text { Active } \\
\text { processing }\end{array}$ \\
\hline $\begin{array}{l}\text { Bos, C.S., \& Anders, P.L. (1990). Effects of } \\
\text { interactive vocabulary instruction on the } \\
\text { vocabulary learning and reading comprehension } \\
\text { of junior-high learning disabled students. } \\
\text { Learning Disability Quarterly, 13(1), 31-42. }\end{array}$ & $\begin{array}{l}\text { - Definition } \\
\text { - Semantic mapping } \\
\text { - Semantic feature analysis } \\
\text { - Semantic/syntactic feature analysis } \\
\text { a }\end{array}$ & $\begin{array}{l}\text { No } \\
\text { Yes } \\
\text { Yes } \\
\text { Yes }\end{array}$ \\
\hline $\begin{array}{l}\text { Bos, C.S., \& Anders, P.L. (1992). Using } \\
\text { interactive teaching and learning strategies to } \\
\text { promote text comprehension and content } \\
\text { learning for students with learning disabilities. } \\
\text { International Journal of Disability Development } \\
\text { and Education, 39(3), 225-238. }\end{array}$ & $\begin{array}{l}\text { - Definition } \\
\text { - Interactive strategies (semantic feature analysis, } \\
\text { semantic mapping) }\end{array}$ & $\begin{array}{l}\text { No } \\
\text { Yes }\end{array}$ \\
\hline $\begin{array}{l}\text { Bos, C.S., Anders, P.L., Filip, D., \& Jaffe, L.E. } \\
\text { (1989). The effects of an interactive instructional } \\
\text { strategy for enhancing reading comprehension } \\
\text { and content area learning for students with } \\
\text { learning disabilities. Journal of Learning } \\
\text { Disabilities, 22(6), 384-390. }\end{array}$ & $\begin{array}{l}\text { - Dictionary } \\
\text { - Semantic feature analysis }{ }^{a}\end{array}$ & $\begin{array}{l}\text { No } \\
\text { Yes }\end{array}$ \\
\hline $\begin{array}{l}\text { Greene Brabham, E., \& Lynch-Brown, C. } \\
\text { (2002). Effects of teachers' reading-aloud styles } \\
\text { on vocabulary acquisition and comprehension of } \\
\text { students in the early elementary grades. Journal } \\
\text { of Educational Psychology, 94(3), 465-473. }\end{array}$ & $\begin{array}{l}\text { - Exposure to words in read-aloud } \\
\text { - Performance (word meanings discussed after } \\
\text { reading) } \\
\text { - Interactional (word meanings discussed during } \\
\text { reading) }\end{array}$ & $\begin{array}{l}\text { No } \\
\text { Yes } \\
\text { Yes }\end{array}$ \\
\hline $\begin{array}{l}\text { Hawkins, R.O., Musti-Rao, S., Hale, A.D., } \\
\text { McGuire, S., \& Hailley, J. (2010). Examining } \\
\text { listening previewing as a classwide strategy to } \\
\text { promote reading comprehension and } \\
\text { vocabulary. Psychology in the Schools, 47(9), } \\
\text { 903-916. }\end{array}$ & $\begin{array}{l}\text { - Exposure to words in silent reading } \\
\text { - Listening preview (exposure to words as teacher } \\
\text { reads text aloud) } \\
\text { - Listening preview plus vocabulary preview } \\
\text { (teacher provides definition plus example }^{\text {sentences) }}\end{array}$ & $\begin{array}{l}\text { No } \\
\text { No } \\
\text { No }\end{array}$ \\
\hline $\begin{array}{l}\text { Kame'enui, E.J., Carnine, D.W., \& Freschi, R. } \\
\text { (1982). Effects of text construction and } \\
\text { instructional procedures for teaching word } \\
\text { meanings on comprehension and recall. } \\
\text { Reading Research Quarterly, 17(3), 367-388. }\end{array}$ & $\begin{array}{l}\text { - Exposure to words in easy vocabulary passage } \\
\text { - Exposure to words in difficult vocabulary } \\
\text { passage } \\
\text { - Exposure to words in difficult vocabulary } \\
\text { passages with additional information about }\end{array}$ & $\begin{array}{l}\text { No } \\
\text { No } \\
\text { No }\end{array}$ \\
\hline
\end{tabular}




\begin{tabular}{|c|c|c|}
\hline & $\begin{array}{l}\text { vocabulary meanings contained in text } \\
\text { - Exposure to difficult vocabulary passage plus } \\
\text { vocabulary training }^{a} \\
\text { - Exposure to difficult vocabulary with vocabulary } \\
\text { integration training (vocabulary reviewed during } \\
\text { reading) }\end{array}$ & $\begin{array}{l}\text { Yes } \\
\text { Yes }\end{array}$ \\
\hline $\begin{array}{l}\text { McKeown, M.G., \& Beck, I.L. (2014). Effects of } \\
\text { vocabulary instruction on measures of language } \\
\text { processing: Comparing two approaches. Early } \\
\text { Childhood Research Quarterly, 29(4), 520-530. }\end{array}$ & $\begin{array}{l}\text { - Repeated read-alouds with teacher providing } \\
\text { child-friendly definitions, matching words to } \\
\text { definitions } \\
\text { - Interactive: Read-alouds plus child-friendly } \\
\text { definitions focused on a variety of contexts; in } \\
\text { follow-up, students respond to situations focused } \\
\text { on usage of word in different contexts } \\
\text { - Read-aloud only }\end{array}$ & $\begin{array}{l}\text { Yes (less) } \\
\text { Yes (more) }\end{array}$ \\
\hline $\begin{array}{l}\text { McKeown, M.G., Beck, I.L., Omanson, R.C., \& } \\
\text { Perfetti, C.A. (1983). The effects of long-term } \\
\text { vocabulary instruction on reading } \\
\text { comprehension: A replication. Journal of } \\
\text { Literacy Research, 15(1), 3-18. }\end{array}$ & $\begin{array}{l}\text { - Some instruction on word meanings } \\
\text { - Many opportunities to learn word meanings }{ }^{a}\end{array}$ & $\begin{array}{l}\text { Yes } \\
\text { Yes }\end{array}$ \\
\hline $\begin{array}{l}\text { McKeown, M.G., Beck, I.L., Omanson, R.C., \& } \\
\text { Pople, M.T. (1985). Some effects of the nature } \\
\text { and frequency of vocabulary instruction on the } \\
\text { knowledge and use of words. Reading } \\
\text { Research Quarterly, 20(5), 522-535. }\end{array}$ & $\begin{array}{l}\text { - Traditional (definitions) } \\
\text { - Rich (explored various aspects of word } \\
\text { meanings) } \\
\text { - Extended rich (rich plus out-of-school activity) }\end{array}$ & $\begin{array}{l}\text { No } \\
\text { Yes } \\
\text { Yes }\end{array}$ \\
\hline $\begin{array}{l}\text { Nash, H., \& Snowling, M. (2006). Teaching new } \\
\text { words to children with poor existing vocabulary } \\
\text { knowledge: A controlled evaluation of the } \\
\text { definition and context methods. International } \\
\text { Journal of Language \& Communication } \\
\text { Disorders, 41(3), 335-354. }\end{array}$ & $\begin{array}{l}\cdot \text { - Dictionary } \\
\text { - Context (made semantic map) }\end{array}$ & $\begin{array}{l}\text { No } \\
\text { Yes }\end{array}$ \\
\hline $\begin{array}{l}\text { Reinking, D., \& Rickman, S.S. (1990). The } \\
\text { effects of computer-mediated texts on the } \\
\text { vocabulary learning and comprehension of } \\
\text { intermediate-grade readers. Journal of Literacy } \\
\text { Research, 22(4), 395-411. }\end{array}$ & $\begin{array}{l}\text { - Paper text and dictionary } \\
\text { - Paper text and glossary } \\
\text { - Computer text and select definitions (students } \\
\text { select whether to look at definitions) } \\
\text { - Computer text and all (students must look at } \\
\text { definitions) }^{\text {a }}\end{array}$ & $\begin{array}{l}\text { No } \\
\text { No } \\
\text { No } \\
\text { No }\end{array}$ \\
\hline Stahl, S. (1983). Differential word knowledge & - Definition (discussed meanings, generated own & Yes \\
\hline
\end{tabular}




\begin{tabular}{|c|c|c|}
\hline $\begin{array}{l}\text { and reading comprehension. Journal of Reading } \\
\text { Behavior, 15(4), 33-47. }\end{array}$ & $\begin{array}{l}\text { definitions) }^{\mathrm{a}} \\
\text { - Definition plus contextual information (discussed } \\
\text { meanings and different usages) }{ }^{\mathrm{a}}\end{array}$ & Yes \\
\hline $\begin{array}{l}\text { Tuinman, J.J., \& Brady, M.E. (1974). How does } \\
\text { vocabulary account for variance on reading } \\
\text { comprehension tests? A preliminary } \\
\text { instructional analysis. In P.L. Nacke (Ed.), 23rd } \\
\text { yearbook of the National Reading Conference } \\
\text { (pp. 176-184). Clemson, SC: National Reading } \\
\text { Conference. }\end{array}$ & $\begin{array}{l}\text { - Learned list A and explored various aspects of } \\
\text { word meanings (self-instructional) } \\
\text { - Learned list B and explored various aspects of } \\
\text { word meanings (self-instructional) }\end{array}$ & Yes \\
\hline $\begin{array}{l}\text { Türk, E., \& Erçetin, G. (2014). Effects of } \\
\text { interactive versus simultaneous display of } \\
\text { multimedia glosses on L2 reading } \\
\text { comprehension and incidental vocabulary } \\
\text { learning. Computer Assisted Language } \\
\text { Learning, 27(1), 1-25. }\end{array}$ & $\begin{array}{l}\text { - Interactive gloss display (learner selects visual } \\
\text { or verbal gloss) } \\
\text { - Simultaneous gloss display (verbal and visual } \\
\text { information in single gloss) }\end{array}$ & $\begin{array}{l}\text { No } \\
\text { No }\end{array}$ \\
\hline $\begin{array}{l}\text { Wixson, K.K. (1986). Vocabulary instruction and } \\
\text { children's comprehension of basal stories. } \\
\text { Reading Research Quarterly, 21(3), 317-329. }\end{array}$ & $\begin{array}{l}\text { - Dictionary and wrote sentence }{ }^{a} \\
\text { - Concept (learn words as concepts through } \\
\text { examples and nonexamples and discussions of } \\
\text { critical features) }^{\text {a }}\end{array}$ & $\begin{array}{l}\text { Yes (less) } \\
\text { Yes (more) }\end{array}$ \\
\hline
\end{tabular}

${ }^{a}$ Significant differences compared with other conditions not marked with ${ }^{a}$ on taught-word comprehension.

[COMP: Please hang turnovers in lists.]

TABLE 4

Direct Teaching of Word Meanings Compared With Control on Generalized Comprehension

\begin{tabular}{|l|l|l|c|}
\hline \multicolumn{1}{|l|}{ Study } & $\begin{array}{l}\text { Description of } \\
\text { direct teaching }\end{array}$ & Duration & $\begin{array}{c}\text { Minutes of } \\
\text { instruction } \\
\text { per word }\end{array}$ \\
\hline $\begin{array}{l}\text { Apthorp, H.S. (2006). Effects of a supplemental vocabulary program } \\
\text { in third-grade reading/language arts. The Journal of Educational } \\
\text { Research, 100(2), 67-79. }\end{array}$ & $\bullet$ Multifaceted & $\begin{array}{l}\text { Long- } \\
\text { term }\end{array}$ & 14 \\
\hline $\begin{array}{l}\text { McKeown, M.G., Beck, I.L., Omanson, R.C., \& Pople, M.T. (1985). } \\
\text { Some effects of the nature and frequency of vocabulary instruction } \\
\text { on the knowledge and use of words. Reading Research Quarterly, } \\
20(5), 522-535 .\end{array}$ & $\bullet$ Multifaceted & Brief & 15 \\
\hline $\begin{array}{l}\text { Nash, H., \& Snowling, M. (2006). Teaching new words to children } \\
\text { with poor existing vocabulary knowledge: A controlled evaluation of }\end{array}$ & • Context & term & 15 \\
\hline
\end{tabular}




\begin{tabular}{|c|c|c|c|}
\hline $\begin{array}{l}\text { the definition and context methods. International Journal of } \\
\text { Language \& Communication Disorders, 41(3), 335-354. }\end{array}$ & (semantic map) & & \\
\hline $\begin{array}{l}\text { Nelson, J.R., \& Stage, S.A. (2007). Fostering the development of } \\
\text { vocabulary knowledge and reading comprehension though } \\
\text { contextually-based multiple meaning vocabulary instruction. } \\
\text { Education \& Treatment of Children, 30(1), 1-22. }\end{array}$ & - Multifaceted ${ }^{\mathrm{a}}$ & $\begin{array}{l}\text { Long- } \\
\text { term }\end{array}$ & 15 \\
\hline $\begin{array}{l}\text { Apthorp, H., Randel, B., Cherasaro, T., Clark, T., McKeown, M., \& } \\
\text { Beck, I. (2012). Effects of a supplemental vocabulary program on } \\
\text { word knowledge and passage comprehension. Journal of Research } \\
\text { on Educational Effectiveness, 5(2), 160-188. }\end{array}$ & - Multifaceted & $\begin{array}{l}\text { Long- } \\
\text { term }\end{array}$ & $6-17$ \\
\hline $\begin{array}{l}\text { Beck, I.L., Perfetti, C.A., \& McKeown, M.G. (1982). Effects of long- } \\
\text { term vocabulary instruction on lexical access and reading } \\
\text { comprehension. Journal of Educational Psychology, 74(4), 506-521. }\end{array}$ & - Multifaceted ${ }^{\mathrm{a}}$ & $\begin{array}{l}\text { Long- } \\
\text { term }\end{array}$ & 22 \\
\hline $\begin{array}{l}\text { Simmons, D., Hairrell, A., Edmonds, M., Vaughn, S., Larsen, R., } \\
\text { Wilson, V., ... Byrns, G. (2010). A comparison of multiple strategy } \\
\text { methods: Effects on fourth-grade students' general and content- } \\
\text { specific reading comprehension and vocabulary development. } \\
\text { Journal of Research on Educational Effectiveness, 3(2), 121-156. }\end{array}$ & $\begin{array}{l}\text { - Multifaceted } \\
\text { - Comprehension } \\
\text { strategies }\end{array}$ & $\begin{array}{l}\text { Long- } \\
\text { term }\end{array}$ & 26 \\
\hline $\begin{array}{l}\text { Lesaux, N.K., Kieffer, M.J., Faller, S.E., \& Kelley, J.G. (2010). The } \\
\text { effectiveness and ease of implementation of an academic } \\
\text { vocabulary intervention for linguistically diverse students in urban } \\
\text { middle schools. Reading Research Quarterly, 45(2), 196-228. }\end{array}$ & $\begin{array}{l}\text { - Primarily } \\
\text { multifaceted, with } \\
\text { some } \\
\text { morphology } \\
\text { (strategy) } \\
\text { instruction }\end{array}$ & $\begin{array}{l}\text { Long- } \\
\text { term }\end{array}$ & 45 \\
\hline $\begin{array}{l}\text { Lesaux, N.K., Kieffer, M.J., Kelley, J.G., \& Harris, J.R. (2014). } \\
\text { Effects of academic vocabulary instruction for linguistically diverse } \\
\text { adolescents: Evidence from a randomized field trial. American } \\
\text { Educational Research Journal, 51(6), 1159-1194. }\end{array}$ & $\begin{array}{l}\text { - Primarily } \\
\text { multifaceted, with } \\
\text { some } \\
\text { morphology } \\
\text { (strategy) } \\
\text { instruction }\end{array}$ & $\begin{array}{l}\text { Long- } \\
\text { term }\end{array}$ & 59 \\
\hline
\end{tabular}

${ }^{a}$ Significant differences compared with no-treatment control on generalized comprehension measure.

[COMP: Please hang turnovers in lists.]

TABLE 5

Studies of Strategy Instruction on Generalized Comprehension Outcomes

\section{Study}

Description of strategy instruction

This article is protected by copyright. All rights reserved 


\begin{tabular}{|c|c|}
\hline $\begin{array}{l}\text { Baumann, J.F., Edwards, E.C., Boland, E.M., Olejnik, S., \& Kame'enui, E.J. } \\
\text { (2003). Vocabulary tricks: Effects of instruction in morphology and context on } \\
\text { fifth-grade students' ability to derive and infer word meanings. American } \\
\text { Educational Research Journal, 40(2), 447-494 }\end{array}$ & $\begin{array}{l}\text { - Morphemic/context clues } \\
\text { - Direct instruction of content } \\
\text { vocabulary }\end{array}$ \\
\hline $\begin{array}{l}\text { Baumann, J.F., Edwards, E.C., Font, G., Tereshinski, C.A., Kame'enui, E.J., } \\
\text { \& Olejnik, S. (2002). Teaching morphemic and contextual analysis to fifth- } \\
\text { grade students. Reading Research Quarterly, 37(2), 150-176. }\end{array}$ & $\begin{array}{l}- \text { - Morphemic } \\
\text { - Context cues } \\
\text { - Morphemic-context }\end{array}$ \\
\hline $\begin{array}{l}\text { Hafner, L.E. (1965). A one-month experiment in teaching context aids in fifth } \\
\text { grade. The Journal of Educational Research, 58(10), 472-474. }\end{array}$ & $\begin{array}{l}\text { - Context clues } \\
\text { - No-treatment control }\end{array}$ \\
\hline $\begin{array}{l}\text { Lubliner, S., \& Smetana, L. (2005). The effects of comprehensive vocabulary } \\
\text { instruction on Title I students' metacognitive word-learning skills and reading } \\
\text { comprehension. Journal of Literacy Research, 37(2), 163-200. }\end{array}$ & $\begin{array}{l}\text { - Comprehensive vocabulary } \\
\text { development }^{\mathrm{a}} \\
\text { - No treatment (above-average } \\
\text { readers) }^{\mathrm{a}}\end{array}$ \\
\hline $\begin{array}{l}\text { Sampson, M.R., Valmont, W.J., \& Van Allen, R. (1982). The effects of } \\
\text { instructional cloze on the comprehension, vocabulary, and divergent } \\
\text { production of third-grade students. Reading Research Quarterly, 17(3), 389- } \\
399 .\end{array}$ & $\begin{array}{l}\text { - } \text { Cloze exercises }^{\mathrm{b}} \\
\text { - No treatment }\end{array}$ \\
\hline $\begin{array}{l}\text { Tomesen, M., \& Aarnoutse, C. (1998). Effects of an instructional programme } \\
\text { for deriving word meanings. Educational Studies, 24(1), 107-128. }\end{array}$ & $\begin{array}{l}\text { - Context clues } \\
\text { - No treatment }\end{array}$ \\
\hline $\begin{array}{l}\text { Zipke, M., Ehri, L.C., \& Cairns, H.S. (2009). Using semantic ambiguity } \\
\text { instruction to improve third graders' metalinguistic awareness and reading } \\
\text { comprehension: An experimental study. Reading Research Quarterly, 44(3), } \\
\text { 300-321. }\end{array}$ & $\begin{array}{l}\text { - Metalinguistic ambiguity } \\
\text { instruction (analyzed multiple } \\
\text { meanings of words and sentences) } \\
\text { - Unrelated instructional control } \\
\text { (read and discussed books) }\end{array}$ \\
\hline
\end{tabular}

a'In this study, the goal of this intervention was for Title I students to catch up to readers in an above-average school; therefore, no differences at posttest was an important finding. ${ }^{b}$ Significant differences compared with other conditions on the comprehension measure.

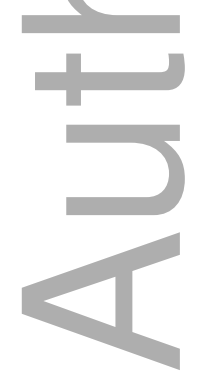

This article is protected by copyright. All rights reserved 